\title{
DEFENDING A SENTENCE: THE JUDICIAL ESTABLISHMENT OF SENTENCING ENTRAPMENT AND SENTENCING MANIPULATION DEFENSES
}

\author{
JOAN MALMUD ${ }^{\dagger}$ \\ INTRODUCTION
}

As drug dealers, Stephanie and Keith Anthony Cannon needed to protect their business. ${ }^{1}$ They needed guns and turned to Sherbrooke, a man with a ready supply. ${ }^{2}$ The Cannons did not know that Sherbrooke was also an undercover police officer. ${ }^{3}$ The Cannons met Sherbrooke four times. During the first three meetings the Cannons bought five handguns from Sherbrooke and stated that they wished to buy more. ${ }^{4}$ At the fourth meeting, Sherbrooke introduced the Cannons to a man named Keating who-unbeknownst to the Cannonswas also an undercover agent. ${ }^{5}$ The Cannons expected to sell cocaine to Keating and Sherbrooke and to purchase handguns from them. ${ }^{6}$ Keating and Sherbrooke, however, planned to arrest the Cannons. Although the Cannons had never requested a machine gun, Keating brought one along to the meeting." "After additional conversation, and some salesmanship by [Sherbrooke] and [Keating], [the Cannons] also purchased one of the machine guns. The guns were not

† B.A. 1993, Williams College; J.D. Candidate 1998, University of Pennsylvania. I would like to thank Professor David Rudovsky for his comments on an earlier draft and Professor Pamela Harris for her guidance throughout. I am also indebted to Ryan Pearson, Giles Cohen and Peter Ryan for their advice and editorial skill. Finally, I would like to thank my fellow Associate Editors who, while under the pressure of impending exams, devoted considerable attention to editing and improving this Comment: Peter Bober, Robyn Ettricks, Jennifer Silver, Michael Stack, Tim Stelzig, Melinda Sutton, Brett Sweitzer, Chad Tang and Lisa Weinman.

${ }^{1}$ See United States v. Cannon, 886 F. Supp. 705 (D.N.D. 1995), rev'd, 88 F.3d 1495 (8th Cir. 1996).

\footnotetext{
${ }^{2}$ See Cannon, 88 F.3d at 1499.

See Cannon, 886 F. Supp. at 706.

4 See id.

5 See Cannon, 88 F.3d at 1499.

6 See Cannon, 886 F. Supp. at 706.

${ }^{7}$ See id.
} 
loaded and no ammunition was included in the sale." ${ }^{8}$ The Cannons left the meeting and were immediately arrested.

Things got worse for the defendants. A federal statute "imposes a mandatory five year sentence for the use of a firearm, but increases the term to thirty years if the firearm is a machine gun." Thus, because Keating had the foresight to bring a machine gun, the Cannons, who had held "an unloaded machine gun in [their] possession... for a matter of moments," faced an additional twenty-five years in prison. ${ }^{10}$

The district court refused to sentence the defendants to an extra twenty-five years in prison. The court noted that " $[t]$ here was no legitimate law enforcement purpose served" by selling the machine gun." "The decision to arrest had been made prior to the meeting, and the presence of the machineguns [sic] could not make the defendants any more guilty of the offense than they would have been if only handguns had been...purchased."12 Because "the machineguns [sic] were nothing more than a gratuitous experiment" to increase the defendants' sentence by six-fold, the court held that the officers' conduct constituted sentencing manipulation, and as a result excluded the machine gun from consideration at sentencing. ${ }^{13}$

The Cannons' case is one among many. Under the recently adopted Federal Sentencing Guidelines ("Sentencing Guidelines" or "Guidelines"), crimes are quantified based upon the amount of harm caused. ${ }^{14}$ In the Cannons' case, the guns were quantified. A firearm was worth five years, a machine gun twenty-five more. The Sentenc-

${ }^{8} I d$. at 708. The Eighth Circuit viewed the facts differently. Whereas the district court stressed the police officers' initiative in delivering unasked-for machine guns, see id. at 706, the court of appeals stressed the defendants' interest and enthusiasm in purchasing the machine guns once they were brought to the meeting, see Cannon, 88 F.3d at 1505, and the reasonableness of the officers' conduct, see id. at 1507.

9 Cannon, 886 F. Supp. at 707 (citing 18 U.S.C. $\$ 924(c)(1)(1994)$ ).

10 Id. at 708.

${ }^{11} I d$.

12 Id.

1s Id. at 708-09. The judgment of the district court was eventually reversed, not due to the district court's finding of sentencing manipulation, but rather due to prosecutorial misconduct during closing arguments. See Cannon, 88 F.3d at 1503. Nonetheless, the Eighth Circuit made it clear it would not countenance the district court's findings of sentencing manipulation. The Eighth Circuit found that the defendants were predisposed to purchase the machine guns, see id. at 1505, and that "the officers' conduct in this case was not so shocking that it crossed over the constitutional line," id. at 1507.

${ }^{14} \mathrm{See}$ U.S. SENTENCING GUIDELINES MANUAL 45 (1995). 
ing Guidelines rarely account for individual and extenuating circumstances. Thus, the fact that the Cannons may not have been predisposed to purchase the machine guns or the fact that the undercover agents might have encouraged them to purchase the machine guns was irrelevant to their sentences. As a consequence, undercover agents such as Keating and Sherbrooke can structure their stings and busts to maximize sentences. Some courts have responded, as the Cannon district court did, by adopting sentencing manipulation or sentencing entrapment as defenses to the sentences that would otherwise be imposed by the Sentencing Guidelines.

This Comment inquires into the authority of a federal court to adopt new sentencing defenses. Part I explains the desirability of sentencing entrapment and sentencing manipulation as defenses against sentences that would otherwise be imposed by the Sentencing Guidelines. Both sentencing entrapment and sentencing manipulation defenses would mitigate the harsh consequences of the Sentencing Guidelines, counter improper police conduct, and tailor sentences to fit a defendant's culpability.

The desirability of a defense, however, does not necessarily give a court the authority to adopt it. Part II defines sentencing entrapment and sentencing manipulation. Because these defenses are still in their formative years, no single definition for either defense has emerged. For purposes of this Comment, a careful definition of each defense is important because whether a court has the authority to establish a defense depends on what the defense purports to do. Part III considers the possible legal foundations of the sentencing entrapment and sentencing manipulation defenses. This Comment concludes that a court would be overstepping its authority if it adopted either the sentencing entrapment or sentencing manipulation defenses. Yet, the problems of police misconduct and sentences unrelated to culpability remain. Thus, Part IV considers which branch, if not the judicial branch, could best formulate a remedy.

\section{DEVELOPMENT OF SENTENCING DEFENSES: THE FEDERAI SENTENCING GUIDELINES AND PROBLEMS THEREIN}

\section{A. Sentencing Before 1984: The Height of Judicial Discretion}

Sentencing entrapment and sentencing manipulation would not exist were it not for recent changes in the way federal courts sentence 
criminals. Prior to 1984, judges possessed extraordinary discretion in sentencing defendants. ${ }^{15}$ While Congress set maximum sentences, a judge could impose a sentence anywhere up to that maximum. ${ }^{16} \mathrm{~A}$ judge did not have to write an opinion explaining how she arrived at a particular sentence. ${ }^{17}$ Nor were sentences generally appealable. ${ }^{18}$ Because judges had few guidelines beyond their own discretion, "disparity in sentencing was the norm." ${ }^{\text {"19 }}$ As similarly situated defendants received widely disparate sentences, criticism of the sentencing system increased. ${ }^{20}$

${ }^{15}$ See Marvin E. Frankel, Lawlessness in Sentencing, 41 U. CIN. L. REV. 1, 1 (1972) (describing this system as "a bizarre 'non-system' of extravagant powers"); see also Robert S. Johnson, The Ills of the Federal Sentencing Guidelines and the Search for a Cure: Using Sentence Entrapment to Combat Governmental Manipulation of Sentencing, 49 VAND. L. REV. 197, 198 (1996) ("Under the old sentencing system, discretion over sentencing resided with judges." (footnote omitted)); Robert Eldridge Underhill, Sentence Entrapment: A Casualty of the War on Crime, 1994 ANN. SURV. AM. L. 165, 180 ("[F]ederal judges, under a so-called indeterminate scheme, had virtually unreviewable power to impose sentences upon the convicted."). In United States v. Staufer, 38 F.3d 1103, 1107-08 (9th Cir. 1994), the court lamented its loss of discretion under the Sentencing Guidelines and noted that without that discretion the courts could no longer control governmental abuses.

${ }^{16}$ See Johnson, supra note 15, at 203 ("Congress provided only a broad sentencing range, sometimes between zero and twenty-five years." (footnote omitted)); Underhill, supra note 15, at 180 ( $[\mathrm{M}]$ ost federal statutes merely set maximum penalties and permitted judicial discretion up to that point.").

${ }^{17}$ See Johnson, supra note 15, at 203 ("[T] he judge was not obligated to give reasons for the sentence.....); Underhill, supra note 15, at 181 ("Prior to the [Federal Sentencing] Guidelines, judges were not even required to write opinions supporting their sentences.").

${ }^{18}$ See Johnson, supra note 15, at 203. One report noted that in the Second Circuit the same case might produce sentences ranging from three to twenty years of imprisonment. See id. at 202 (citing ANTHONY PARTRIDGe \& WILlIAM B. EldRIDGE, THE SECOND CIRCUIT SENTENCING STUDY: A REPORT TO THE JUDGES OF THE SECOND CIRCUIT 1-3 (Federal Judicial Center, 1974)). Sentences also varied according to geography, race and gender. For instance, in the South, sentences for the same crime tended to be six months longer than the national average. In California, sentences were 12 months shorter than the national average. Male bank robbers served six months longer than female bank robbers, and black bank robbers convicted in the South served approximately thirteen months longer than similarly situated bank robbers in other geographical regions. See id. (citing Sentencing Guidelines, Hearings on $H . R .3307$ Before the Subcomm. on Criminal Justice of the House Comm. on the Judiciary, 100th Cong. 665, 675-77 (1987) (statement of Ilene H. Nagel, Commissioner, Sentencing Commission)).

${ }^{19} I d$. at 201 (footnote omitted).

${ }^{20}$ See Underhill, supra note 15 , at 165 (" $[\mathrm{M}]$ any commentators viewed uncontrolled judicial discretion as the principal vice of the then existing system." (footnote omitted)); see also id. at 180 ("As faith in rehabilitation failed and fear of crime increased, the indeterminate approach in general, and judicial discretion specifically, received widespread criticism."). Broad judicial discretion was not the only subject of 


\section{B. Reform and the Sentencing Guidelines: Quantity-Driven Punishment}

In 1984, in response to the criticisms, Congress enacted the Sentencing Reform Act. ${ }^{21}$ The Sentencing Reform Act created the United States Sentencing Commission ("Commission") as an agency within the judiciary. ${ }^{22}$ Over the next three years, the Commission developed the Sentencing Guidelines, which went into effect in $1987 .^{23}$

Through the Sentencing Guidelines, the Commission sought to achieve uniformity in sentencing. ${ }^{24}$ "Uniformity in sentencing" means that similar criminals, committing similar crimes, will receive substantially similar sentences. ${ }^{25}$ To achieve uniformity, the Commission established a 258-box grid. Along one axis of the grid lies the severity of the offense. To the extent possible, the Commission quantified the severity of an offense. ${ }^{26}$ For example, in the case of drug crimes the severity of the offense is based on the amount of drugs a defendant has bought, sold or possessed. ${ }^{27}$ In economic crimes such as

complaints regarding the pre-1984 sentencing structure. Critics also attacked the parole system which determined the actual length of a sentence served. See Johnson, supra note 15, at 202 ("Since the Parole Commission controlled when a prisoner would be released, the sentence imposed by a judge was not the actual amount of time a defendant would serve." (footnote omitted)). Parole added another element of disparity to the system. See id. ("[A] judge might sentence a defendant to twelve years, but the Parole Commission could release him after four." (footnote omitted)).

${ }^{21}$ Sentencing Reform Act of 1984, Pub. L. No. 98-473, 98 Stat. 2019 (codified as amended in scattered sections of 18 U.S.C. and 28 U.S.C. (1994)).

${ }^{22}$ See 28 U.S.C. $\$ 991$ (1994).

${ }^{23}$ See U.S. SEnTENCING GuIdelines Manual 2 (1995). The Commission submitted the proposed Guidelines to Congress for review on April 13, 1987. The Guidelines "took effect on November 1, 1987, and apply to all offenses committed on or after that date." Id. at 1 .

${ }^{24}$ See id. at 2. The Commission had three goals it sought to achieve through the Guidelines: honesty, uniformity and proportionality in sentencing. See id. "Honesty in sentencing" meant that a defendant would serve the actual length of the sentence imposed by the court, rather than be released on parole before the sentence was halfserved; this required the abolition of the parole system. See id. at 1-2. "Proportionality in sentencing" meant that the Guidelines would impose "appropriately different sentences for criminal conduct of differing severity" and of differing harm. See id. at 2. However, Commissioner Ilene Nagel admitted that "the Sentencing Commission was more concerned with uniformity-making sentences alike, than with proportionality-insuring the likeness of those grouped together for similar sentences." Johnson, supra note 15, at 206.

${ }_{25}$ See U.S. Sentencing Guidelines Manual 2 (1995).

${ }^{26}$ See Underhill, supra note 15, at 192 ("In creating proportionality in sentencing, Congress sought to punish larger quantities of certain crimes more severely because they were considered more harmful.").

27 See U.S. SENTENCING Guidelines MANUAL § 2D1.1; see also Sandra Guerra, The New Sentencing Entrapment and Sentence Manipulation Defenses, 7 FED. SENTENCING REP. 
fraud, money laundering, bribery or counterfeiting, the severity of an offense is determined by the amount of money involved in the illicit transaction. ${ }^{28}$ Additionally, a criminal's sentence might be stepped up due to an aggravating factor such as the presence of a gun, ${ }^{29}$ the transaction's proximity to a school, ${ }^{30}$ or the involvement of a pregnant woman in the transaction. ${ }^{31}$

Along the other axis of the grid lie the offender's characteristics. The Guidelines limit the personal characteristics a judge may consider. Initially, Congress indicated that a judge could consider a "defendant's age, education, vocational skills, mental and emotional condition, physical condition (including drug dependence), previous employment record, family ties and responsibilities, community ties, role in the offense, criminal history, and dependence upon criminal activity for a livelihood."32 Additionally, a judge was supposed to consider the defendant's state of mind as well as her purpose in committing the crime. ${ }^{33}$ By the time the Commission submitted its proposed Sentencing Guidelines to Congress, only three factors were deemed relevant to setting a sentencing range: (1) a defendant's past criminal history; (2) her dependence upon the criminal activity for her livelihood; and (3) her acceptance of responsibility for the crime. ${ }^{34}$ In 1989, the requirement that judges consider a defendant's motives was deleted as "unnecessary." In this way, the focus of the Sentenc-

181,181 (1995) (" $[T]$ he total amount of drugs for which an offender is held accountable will determine the length of the sentence.").

${ }^{28}$ See U.S. SENTENCING GUIDELINES MANUAL $\$ 2 F 1.1(b)$ (1) (fraud and deceit); $\S 2 \mathrm{S1.1(b)}$ (money laundering); $\S 2 \mathrm{~B} 4.1$ (commercial bribery); $\S 2 \mathrm{~B} 5.1$ (counterfeiting).

${ }^{29}$ See id. \$ 2D1.1(b)(1).

so See id. §2D1.2(a).

s1 See id.

${ }^{32}$ Charles J. Ogletree, Jr., The Death of Discretion? Reflections on the Federal Sentencing Guidelines, 101 HARV. L. REV. 1938, 1953 (1988).

${ }^{39}$ See Jack B. Weinstein \& Fred A. Bernstein, The Denigration of Mens Rea in Drug Sentencing, 7 FED. SENTENCING REP. 121, 121 (1995).

${ }_{34}$ See Ogletree, supra note 32 , at 1953 . In addition to the three factors that a judge must consider, the Guidelines also lists factors that a judge may not consider. For example:

Section 5H1.10 (Race, Sex, National Origin, Creed, Religion, and SocioEconomic Status), § 5H1.12 (Lack of Guidance as a Youth and Similar Circumstances), the third sentence of $\S 5 \mathrm{H} 1.4$ (Physical Condition, Including Drug Dependence and Alcohol Abuse), and the last sentence of $\S 5 \mathrm{~K} 2.12$ (Coercion and Duress) list several factors that the court cannot take into account as grounds for departure.

U.S. SENTENCING Guidelines MANUAL 6 (1995).

${ }^{35}$ See Weinstein \& Bernstein, supra note 33, at 121 (internal quotations omitted). 
ing Guidelines shifted from considering the defendant to considering only the amount of harm caused. ${ }^{36}$

A judge follows the grid-plotting the severity of the offense against the offender's characteristics-to the appropriate sentencing range and imposes a sentence within that range. The range is narrow. Before the Sentencing Guidelines were enacted, judges were able to choose a sentence anywhere within a range of zero to twentyfive years. ${ }^{98}$ Under the Sentencing Guidelines the maximum possible sentence cannot exceed the minimum by more than twenty-five percent or six months, whichever is greater. ${ }^{39}$

Ostensibly, judges are allowed to depart from the grid if they find that the case at bar presents unusual circumstances. ${ }^{40}$ In practice, however, departures are rare. The Sentencing Guidelines limit departures only to "circumstance[s] of a kind, or to a degree, not adequately taken into consideration by the Sentencing Commission in formulating the guidelines." ${ }^{41}$ and state "that despite the courts' legal freedom to depart from the guidelines, they will not do so very often." ${ }^{\text {"2 }}$ As one court noted, "[f] ew fact situations [we]re not foreseen by the Commission." ${ }^{\text {,39 }}$ Furthermore, since the promulgation of the

${ }^{36}$ See Albert W. Alschuler, The Failure of Sentencing Guidelines: A Plea for Less Aggregation, 58 U. CHI. L. REV. 901, 908-09 (1991) ("It has led to the substitution of crime tariffs for the consideration of situational and offender characteristics ...."); Johnson, supra note 15, at 205.

${ }^{37}$ See Johnson, supra note 15 , at 203. Many judges disfavor the Sentencing Guidelines because, among other reasons, the Guidelines reduce sentencing to mere computation. See, e.g., United States v. Shepherd, 857 F. Supp. 105, 111 (D.D.C. 1994) (lamenting the fact that judges' responsibilities are reduced "to little more than plotting points on a graph and announcing [a] mathematical result"); Jose A. Cabranes, Sentencing Guidelines: A Dismal Failure, N.Y. L.J., Feb. 11, 1992, at 2 (criticizing the computational aspects of the Sentencing Guidelines).

${ }^{33}$ See Johnson, supra note 15, at 203.

${ }^{39}$ See 28 U.S.C. $\$$ 994(b)(2) (1994); U.S SENTENCING GUIDELINES MANUAL 1 (1995).

See 18 U.S.C. \$ 3553(b) (1994); U.S SENTENCING GUIDELINES MANUAL 1 (1995) ("If ... a particular case presents atypical features, the Act allows the court to depart from the guidelines and sentence outside the prescribed range."); id. at 6 ("[T]he Commission does not intend to limit the kinds of factors, whether or not mentioned anywhere else in the guidelines, that could constitute grounds for departure in an unusual case.").

${ }^{4}$ U.S SENTENCING GuIDELINES MANUAI 5 (1995) (citing 18 U.S.C. § 3553(b) (1994)).

${ }^{42} I d$. at 6.

49 Shepherd, 857 F. Supp. at 106 n.1. The court continued by stating that few fact situations were not foreseen "whose product resemble[d] in ... detail, complexity, and its mandatory nature, the Internal Revenue Code rather than what would normally be understood by the term 'guidelines." Id. The Commission expressed the 
Sentencing Guidelines, appellate courts have regularly overturned socalled "downward departures" (the application of a lesser sentence than the Guidelines would otherwise require), ${ }^{44}$ further dissuading district courts from straying. ${ }^{45}$

By quantifying the severity of most offenses, restricting the individual characteristics a court may consider, and limiting the ability to depart from the grid, the Sentencing Guidelines aimed to impose substantially similar sentences on criminals committing similar offenses.

\section{Quantity-Driven Punishment and the Creation of New Problems}

The attempt-through the Sentencing Guidelines-to eliminate the disparities under the old sentencing system, however, gave rise to new problems and criticisms. ${ }^{46}$

\section{Sentences Manipulated by Law Enforcement}

One important criticism levied against the Sentencing Guidelines is that it shifts too much discretion to prosecutors and undercover investigators. ${ }^{47}$ In undercover operations, the prosecutor determines

same belief that most fact patterns had been accounted for. See U.S SENTENCING GUIDELINES MANUAL 6 (1995) ("[T]he guidelines, offense by offense, seek to take account of those factors that the Commission's data indicate made a significant difference in pre-guidelines sentencing practice.").

44 See U.S SENTENCING Guidelines MANUAL 5-6 (1995).

${ }^{45}$ See, e.g., United States v. Harrington, 947 F.2d 956, 968 (D.C. Cir. 1991) (Edwards, J., concurring) ("The appellate cases show a disparity between the relative ease of upward departure and the niggardly application of downward adjustments."); Johnson, supra note 15, at 204 ("[T] he courts of appeals have been very restrictive and have held the trial courts to the Guidelines-mandated sentence even in the most compelling of circumstances.").

${ }^{46}$ See, e.g., Harrington, 947 F.2d at app. 968-70 (Edwards, J., concurring) (listing numerous cases and articles in which judges and commentators have expressed their displeasure with the Guidelines). Whether in fact the Guidelines have succeeded in ameliorating the disparity problem of the pre-Guidelines sentencing regime is disputed. See Cabranes, supra note 37, at 2 ("[T] he 258-box grid ... does not even come close to achieving the asserted objectives of confining discretion and eliminating the bogeyman of disparity.... [D] isparity is ... alive and well."); Deborah Young, Rethinking the Commission's Drug Guidelines: Courier Cases Where Quantity Overstates Culpability, 3 FED. SENTENCING REP. 63, 65 (1990) (noting that "the average sentences in narcotics cases rang[e] from sixty-three months in the Eastern District of New York to one hundred and six months in the Western District of Missouri and Southern District of Florida").

See Underhill, supra note 15, at 165-66 ("With the decrease in judicial discretion, prosecutorial power over sentencing has increased, thus inviting opportunities for 
which individuals to target, the types of criminal activities to investigate, and when to terminate an investigation. ${ }^{48}$ Since sentences are based on the quantity of drugs or amount of money involved, a prosecutor can easily increase a person's sentence by delaying an arrest and thereby allowing more drug buys ${ }^{49}$ or more money to filter through an economic crime. ${ }^{50}$ An undercover agent ${ }^{51}$ can also affect the length of a sentence by choosing the type of drugs sold (the penalty for selling crack cocaine is approximately twice that of selling powder cocaine) ${ }^{52}$ the location of a sale (e.g., near a school), or whether particular firearms are present. ${ }^{53}$ With so many decisions to make and each decision explicitly worth a certain number of months on the sentencing grid, prosecutors and undercover agents can directly influence the sentence a defendant will receive. ${ }^{54}$

abuse.... In undercover sting operations, where the government often controls the execution of the crime, the potential for abuse is heightened.").

${ }^{49}$ See Saul M. Pilchen, The Federal Sentencing Guidelines and Undercover Sting Operations: A Defense Perspective, 4 FED. SENTENCING REP. 115, 115 (1991) (discussing prosecutorial discretion in guiding undercover sting operations).

${ }^{49}$ See, e.g., United States v. Lenfesty, 923 F.2d 1293, 1300 (8th Cir. 1991) (recapping the defendant's charge that the police agent's only motive "in repeatedly purchasing drugs from her was to increase both the amount of drugs in the conspiracy and her sentence"); United States v. Barth, 990 F.2d 422, 424 (8th Cir. 1993) (quoting the district court judge who found that "it was 'not at all fortuitous that the agent arrested [Barth] only after he had arranged enough successive buys to reach the magic number (referring to 50 grams, the quantity that triggers the application of the 10-year mandatory minimum sentence)'").

${ }^{50}$ See, e.g., United States v. Nelson, 988 F.2d 798, 809 (8th Cir. 1993), cert. denied, 114 S. Ct. 302 (1993) (indicating the court's concern that the government had "no legitimate reason for ... [continuing its investigation of fraud charges] as long as it did"); United States v. Kaczmarski, 939 F. Supp. 1176, 1182-83 (E.D. Pa. 1996) (holding that the government had not unnecessarily enlarged the scope of the defendant's bank fraud charges even though the government had determined the amount of checks to be deposited).

${ }^{51}$ Oftentimes, it is not even an undercover agent who is actually performing the investigation. Often, the police engage criminals (i.e., informants) to conduct the sting. See United States v. Staufer, 38 F.3d 1103, 1104-05 (9th Cir. 1994) (finding that DEA agents had a confidential informant buy the hallucinogen LSD as part of a reverse sting operation); Robert Weisberg, Guideline Sentencing, Traditional Defenses, and the Evolution of Substantive Criminal Law Doctrine, 7 FED. SENTENCING REP. 168, 169-70 (1995) (" $[T]$ he most disturbing aspect of sentencing entrapment [is] that the prime entrappers and manipulators are not even governmental officials themselves, but paid informants whose contingent fees may turn directly on the volume of drugs on which sentencing is based.").

${ }^{32}$ See, e.g., United States v. Shepherd, 857 F. Supp. 105, 112 (D.D.C. 1994) (noting that "the defendant's compliance with the agent's demand for cooking the cocaine would add over five years to her sentence").

${ }_{53}$ See supra note 29 and accompanying text.

${ }^{54}$ While many criticize prosecutorial manipulations because they result in longer 


\section{Punishment Unrelated to Culpability}

A second criticism of the Sentencing Guidelines is that the punishments imposed do not accurately reflect a defendant's culpability. ${ }^{55}$ For instance, the Sentencing Guidelines impose longer sentences for larger quantities of drugs. The presumption was that larger quantities would accurately reflect a person's position in a drug-selling organization. $^{56}$ In fact, drug kingpins hire couriers and sellers who, when caught, will be sentenced as if they were kingpins. ${ }^{57}$ The harsh sentences for less culpable defendants occur because judges can consider very few of the individual circumstances surrounding a crime and must base their sentencing decision almost entirely upon the amount of harm involved. ${ }^{58}$

If the prosecutor or the undercover agent is, in fact, orchestrating the illicit conduct to ensure the maximum sentence, further questions arise about a defendant's culpability and whether her sentence is appropriate. For instance, a person may decide to commit one criminal act but not a second criminal act. An undercover agent,

sentences, prosecutors also admit to using manipulation to arrive at lesser sentences. See Johnson, supra note 15, at 206 ( $[$ [P]rosecutors and judges often refrain from imposing enhancements for aggravating factors because they believe the resulting sentence would be far too harsh."); Mary Pat Flaherty \& Robert O. Suro, Reno Criticizes Manipulation of U.S. Sentencing Guidelines, WASH. POST, Oct. 11, 1996, at A4 ("Prosecutors acknowledged ... that ... at times [they] have ignored the use of a gun [or] tinkered with the amounts of drugs ... to reward cooperative defendants ....").

${ }^{55}$ See, e.g., Staufer, 38 F.3d at 1107 (noting that under the Guidelines there is no adequate assurance that a defendant will be sentenced on the basis or the extent of her culpability); United States v. Harrington, 947 F.2d 956 (D.C. Cir. 1991) (Edwards, $\mathrm{J}$., concurring) ("[T]he Guidelines are rigid in formulation and, thus, often produce harsh results that are patently unfair because they fail to take account of individual circumstances that might militate in favor of a properly 'tailored' sentence."); Jeff Staniels, Grading Culpability at Sentencing: The Example of Sentencing Entrapment, 7 FED. SENTENCING REP. 178, 178-80 (1995) (arguing that defendants who commit the same offense do not necessarily deserve the same sentence); Underhill, supra note 15 , at 181 ("Many judges have objected to the fact that the Guidelines lack a mechanism for judges to account for individualized differences in defendants.").

${ }^{36}$ See Johnson, supra note 15, at 206 ("The Guidelines prescribe sentences with the belief that quantity of drugs reflects a defendant's position in the drug hierarchy."). But see Staniels, supra note 55, at 180 \& n.3 (noting that the Guidelines' grading system was supposed to punish drug suppliers more severely than street vendors, but has instead had the reverse effect).

57 See Johnson, supra note 15, at 206-07 (commenting on the fact that kingpins intentionally hire couriers as a measure of protection); Staniels, supra note 55, at $180 \mathrm{n} .3$ (noting that "[s]ubstantial numbers of people who are significantly less culpable than those targeted ... are today filling the prisons").

53 See Young, supra note 46, at 63-66 (discussing the relatively meager opportunities for downward departures in the case of a drug courier). 
knowing that the defendant will be incarcerated longer if she commits a second criminal act, may encourage the individual to commit that second act. ${ }^{59}$ If both acts are in fact committed, the sentencing court will sentence the defendant in accordance with the commission of both crimes without consideration for the defendant's original intent. $^{60}$ This is so, despite the fact that, were it not for the police instigation, the second criminal act might never have been committed. In this way, questions arise whether the punishment in fact matches a defendant's culpability. ${ }^{61}$

\section{The Lower Courts' Response: Sentencing Defenses to Deter Manipulation and Ensure Punishment Related to Culpability}

The courts are clearly troubled by police impropriety and the lack of defendant culpability and have granted downward departures to remedy these problems. In United States $v$. Staufer, ${ }^{62}$ the defendant Staufer was introduced to an undercover agent through a friend who, unbeknownst to Staufer, was a government informant. ${ }^{63}$ At the time that Staufer was being investigated, " $[\mathrm{h}] \mathrm{e}$ had almost no money to his name, ... could not afford to pay rent, and had ... bills that he was

${ }^{59}$ See, e.g., United States v. Cannon, 886 F. Supp. 705 (D.N.D. 1995) (undercover agent encouraging defendants to buy a machine gun as well as handguns and thereby adding 25 years to the defendants' sentence); United States v. Shepherd, 857 F. Supp. 105, 112 (D.D.C. 1994) (undercover agent encouraging defendant to sell crack cocaine as well as powder and thereby adding five years to the defendant's sentence); see also Jeffrey L. Fisher, When Discretion Leads to Distortion: Recognizing Pre-Arrest Sentence Manipulation Claims Under the Federal Guidelines, 94 MICH. L. REV. 2385, 2397 (1996) ("[P]olice officers and agents are a little more savvy about these guidelines. All of a sudden rather than busting at two buys, they're busting after seven buys. What that does is that just raises those guidelines, so those guys are buried." (quoting Gerald W. Heaney, The Reality of Guidelines Sentencing: No End to Disparity, 28 AM. CRIM. L. REV. $161,196 \mathrm{n} .97(1991))$ ).

${ }^{65}$ See, e.g., Cannom, 88 F.3d at 1505-07 (suggesting that the trial court had acted inappropriately when it failed to sentence defendants for possession of handguns and a machine gun).

${ }^{61}$ See Guerra, supra note 27, at 184 ("Presumably a person who sells, buys or transports drugs as a profession is more culpable than one who succumbs to the temptation to make quick cash on one occasion."); Underhill, supra note 15, at 192 (comparing the relative culpability of a defendant who set out to purchase 150 pounds of marijuana with the culpability of a defendant who set out to buy 30 pounds of marijuana but was encouraged and did purchase 150 pounds).

62 38 F.3d 1103 (9th Cir. 1994).

${ }^{69}$ See id. at 1104-05. The court also noted that the confidential informant was "free to contact Staufer as he pleased and received little or no supervision from the government" Id. at 1105. 
unable to pay. ${ }^{\text {} 64}$ Staufer had been able to find only occasional employment, making it difficult for him to maintain a home. Making matters worse, he had been recently robbed, beaten and hospitalized. $^{65}$ When Staufer met the undercover agent, Staufer expressed that he wanted to sell 5000 doses of LSD. The undercover agent, however, insisted that Staufer sell 10,000 doses. When Staufer expressed reluctance, the undercover agent readily suggested that he would pay more. ${ }^{66}$ Further arrangements were made and Staufer did eventually sell the 10,000 doses to the undercover agent. Prior to this incident, Staufer had sold drugs only once before. At that time, Staufer had bought twenty-five to thirty doses of LSD for fifteen dollars. He then sold some of it to friends who gave him eight dollars in return. ${ }^{67}$

Staufer is the first and only case in which a court of appeals has explicitly acknowledged sentencing entrapment as a defense and upheld a downward departure on that basis. ${ }^{68}$ In upholding the downward departure, the court indicated the same two concerns discussed above: that government agents should not manipulate sentences and that the sentence under the Guidelines inaccurately reflected the defendant's culpability. The court stated that:

\begin{abstract}
government abuse can be discouraged and corrected only if courts also are able to ensure ... that defendants are predisposed to engage in a drug deal of the magnitude for which they are prosecuted. Furthermore, courts can ensure that the sentences imposed reflect the defendants' degree of culpability only if they are able to reduce the sentences of defendants who are not predisposed to engage in deals as large as those induced by the government.
\end{abstract}

Similar concerns were voiced by the district court in United States v. Shepherd. ${ }^{70}$ Shepherd was charged with one sale of powder cocaine, two sales of crack cocaine, and the possession of a firearm during one of the transactions. ${ }^{71}$ On the two occasions in which Shepherd sold crack cocaine, she originally intended to sell powder cocaine. The undercover agent, however, insisted that Shepherd convert the pow-

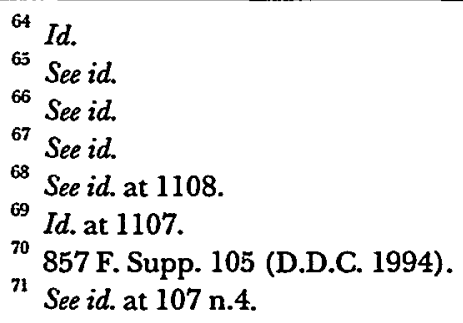


der to crack. ${ }^{72}$ Converting powder cocaine to crack takes only a few minutes of "cooking" in a microwave oven. ${ }^{73}$ The agent was fully aware that if Shepherd converted the powder to crack and then sold it, she would be subject to a much lengthier sentence. ${ }^{74}$ In fact, had Shepherd's sentence been calculated based upon the sales of crack cocaine, she would have received a sentence of ten to eleven years. ${ }^{75}$ The lower court calculated her sentence based on the intended sales of powder cocaine. By that calculation, Shepherd's sentence was reduced by half-to only five years. ${ }^{76}$

The legal basis for the Shepherd court's downward departure is unclear from the decision. The court stated that the police practices denied the defendant her right to "due process" cussed sentencing entrapment and sentencing manipulation. ${ }^{78}$ The court's policy concerns were also made clear in the opinion. The court first focused on the conduct of the law enforcement agent and lamented that " $[t]$ he ability of a law enforcement officer to enhance a defendant's sentence through his own actions to [an] enormous degree strikes at the very heart of our system of justice. ${ }^{79}$ But the court also "believe [d] that justice, fairness and the tailoring of a sentence to address a defendant's actual culpability retain a place within our system. ${ }^{800}$ Accordingly, the Shepherd court "determined that it [was] appropriate to calculate the defendant's sentence... as if the sales had involved only cocaine powder rather than crack. ${ }^{81}$ Whatever the legal basis for its decision, the court obviously was concerned about manipulation of the defendant's sentence by law enforcement and thus attempted to tailor the defendant's sentence to her actual culpability.

${ }^{72}$ See id. at 106.
See id.

74 See id. at 109 ("Agent Ross unquestionably understood the implications of his actions.... [H] e had previously testified, in an unrelated case..., that he has insisted on the conversion of cocaine to crack because he was aware of the heavier sentences imposed on defendants convicted for crack offenses.").

${ }^{75}$ See id. at 106.

76 See id.

77 Id. (stating that because of minimum sentences and the Sentencing Guidelines, effective control of sentencing has shifted from a judicial function to a prosecutorial and even to a police function).

${ }^{78}$ See id. at 111-12 (expressing the court's dismay at "the restraints Congress and the Sentencing Commission have hoist upon sentencing courts in recent years").
Id. at 109 .
${ }^{80} I d$.
${ }^{81} I d$. 


\section{SENTENCING ENTRAPMENT AND SENTENCING MANIPULATION DEFINED}

The terms "sentencing entrapment" and "sentencing manipulation" are closely related and often confused terms. In order to consider whether the courts have the legal authority to adopt new defenses, the definition and goal of each defense must be clear.

\section{A. Sentencing Entrapment}

The term "sentencing entrapment" was coined first. In United States $v$. Lenfesty, ${ }^{82}$ the Eighth Circuit defined sentencing entrapment as "outrageous official conduct [that] overcomes the will of an individual predisposed only to dealing in small quantities [of drugs]. ${ }^{, 83}$ This definition encompasses two ideas: (1) outrageous official conduct and (2) the predisposition of the individual. These two ideas have since been parsed out and applied to two separate defenses. ${ }^{84}$

The sentencing entrapment defense relates to an individual's predisposition. "Sentencing entrapment" is the claim that the defendant, although predisposed to commit a lesser offense, is coerced into committing a greater offense with a correspondingly greater punishment. ${ }^{85}$ The focus of the sentencing entrapment defense is the defendant's mental state-whether she was predisposed to commit the crime to the extent that she did. Staufer is an example of sentencing entrapment. $^{86}$ In Staufer, the defendant initially wanted to sell only

82 923 F.2d 1293 (8th Cir. 1991).

8s Id. at 1300 .

${ }^{84}$ Many but not all courts have distinguished the two defenses. See, e.g., United States v. Garcia, 79 F.3d 74, 75 (7th Cir.) (explaining the separate theories underlying sentencing entrapment and sentencing manipulation), cert. denied, $117 \mathrm{~S}$. Ct. 158 (1996); United States v. Jones, 18 F.3d 1145, 1153 (4th Cir. 1994) (same); United States v. Shephard, 4 F.3d 647, 649 (8th Cir. 1993) (same); see also Amy Levin Weil, In Partial Defense of Sentencing Entrapment, 7 FED. SENTENCING REP. 172, 173 (1995).

While many courts and commentators have made an effort to distinguish the two defenses, confusion and overlap still remain in many court decisions. For the purposes of this Comment, however, sentencing entrapment will refer to a claim based on the defendant's lack of predisposition and sentencing manipulation to a claim of police misconduct.

${ }^{85}$ See United States v. Stuart, 923 F.2d 607, 614 (8th Cir. 1991) ("Sentencing entrapment' as defined by the defendant, posits the situation where a defendant, although predisposed to commit a minor or lesser offense, is entrapped into committing a greater offense subject to greater punishment."); United States v. Staufer, 38 F.3d 1103, 1106 (9th Cir. 1994) (citing the Stuart court's definition); Underhill, supra note 15, at 167 (defining sentencing entrapment).

${ }^{86}$ See Staufer, 38 F.3d at 1103. 
5000 doses of LSD. Upon the undercover agent's insistence and his offer of more money, Staufer sold 10,000 doses. ${ }^{87}$ Because Staufer denied a predisposition to committing the crime to the extent charged, Staufer's is a sentencing entrapment claim.

The Ninth Circuit in Staufer is the only court of appeals to recognize sentencing entrapment and grant a downward departure on that basis. The Eighth Circuit recognizes the defense but has never found facts warranting a downward departure. ${ }^{88}$ The remaining circuits have either rejected sentencing entrapment as a theory, ${ }^{89}$ have not decided whether sentencing entrapment is a recognized defense, ${ }^{90}$ or have recognized sentencing manipulation instead of sentencing entrapment. $^{\text {.1 }}$

\section{B. Sentencing Manipulation}

Whereas sentencing entrapment focuses on the defendant's predisposition, sentencing manipulation focuses on the government's conduct. A sentencing manipulation claim asserts that a defendant should not be sentenced as heavily as strict adherence to the Guidelines would otherwise require because the government acted outrageously or improperly for the sole purpose of increasing the defen-

${ }^{87}$ See id. at 1105; see also supra notes 66-67 and accompanying text.

\&8 See United States v. Stavig, 80 F.3d 1241, 1245 (8th Cir. 1996) ("[W]e have yet to find that sentencing entrapment existed under the facts of a particular case.").

${ }^{89}$ See United States v. Markovic, 911 F.2d 613, 616 (11th Cir. 1990) ("Entrapment as a matter of law is no longer a viable defense in this Circuit.").

${ }^{90}$ See United States v. Steelman, No. 95-5308, 1996 U.S. App. LEXIS 24836, at *2 (4th Cir. Sept. 23, 1996) ("This Court has never explicitly recognized the availability of these theories and does not do so now."); United States v. Lacey, 86 F.3d 956, 963 n.4 (10th Cir.) (indicating that the defense has been raised in the Tenth Circuit but not directly addressed), cert. denied, 117 S. Ct. 331 (1996); United States v. Perez, CRIM.A.Nos. 940192-01 \& 94-0192-10, 1996 WL 502292, at *6 (E.D. Pa. Aug. 27, 1996) ("Our Court of Appeals has not as yet addressed the theory of sentencing entrapment."); United States v. Knecht, 55 F.3d 54, 57 (2d Cir. 1995) ("The validity of the concept of sentencing entrapment has not been determined in this circuit."); United States v. Wright, 48 F.3d 1220 (6th Cir. 1995) (table), No. 93-4228, 1995 WL 101300, at *2 ("This court has not decided whether, under the Guidelines, sentencing entrapment may be a basis for a downward departure."); United States v. Washington, 44 F.3d 1271, 1280 (5th Cir. 1995) ("Until now, however, we have not had occasion to address the viability of [a sentencing entrapment defense], and we conclude that we need not do so today.").

${ }^{91}$ See United States v. Schweihs, 83 F.3d 424 (7th Cir. 1996) (table), No. 95-1974, 1996 WL 218200, at *5; United States v. Villegas, 51 F.3d 264 (1st Cir. 1995) (table), No. 941769, 1995 WL 138498, at*2 n.1. 
dant's sentence. ${ }^{92}$ United States $v$. Cannon, ${ }^{93}$ the case discussed in the introduction to this Comment, is an example of a sentencing manipulation claim. In Cannon, the defendants bought several handguns from an undercover agent. ${ }^{94}$ The undercover agent planned to arrest the defendants after their last meeting. The district court found that while the defendants had never before asked to buy a machine gun, the agent brought one to the final meeting and encouraged the defendants to buy the machine gun knowing that, if the defendants took the bait, the machine gun would add twenty-five years to their sentences. ${ }^{95}$

No court of appeals has departed downward on the basis of a sentencing manipulation claim. ${ }^{96}$ Nonetheless, the First, Sixth, Eighth and Tenth Circuits have to one degree or another recognized some form of sentencing manipulation as a valid defense. ${ }^{97}$ The Seventh

92 See United States v. Garcia, 79 F.3d 74, 75 (7th Cir. 1996) ("Sentencing manipulation occurs when the government engages in improper conduct that has the effect of increasing a defendant's sentence."), cert. denied, 117 S. Ct. 158 (1996); United States v. Jones, 18 F.3d 1145, 1153 (4th Cir. 1994) ("Citing the First Circuit's opinion in [United States v.] Connelh, [960 F.2d 191 (1st Cir. 1992)], the Eighth Circuit adopted the term 'sentence manipulation' for the theory that outrageous government conduct that offends due process could justify a reduced sentence.").

${ }_{93}$ United States v. Cannon, 886 F. Supp. 705 (D.N.D. 1995), rev'd, 88 F.3d 1495 (8th Cir. 1996).

${ }^{94}$ See id. at 706.

95 See id. at 708-09.

${ }^{96}$ See Fisher, supra note 59, at 2406 ("No court that views sentence manipulation as a species of outrageous government conduct has allowed the doctrine to provide a successful partial defense to a quantity-based sentence."). Fisher notes that, of the circuits that have applied a constitutional standard to sentencing manipulation, only one court, the district court in Cannon, has reduced a defendant's sentence based on a sentencing manipulation claim. See id. at 2406 n.108. But even that reduction was not ultimately successful. The case was reversed and remanded for a new trial due to prosecutorial misconduct. See Cannon, 88 F.3d at 1509. While the Eighth Circuit stated that it did not have to reach the question, see id. at 1503 , the court indicated that it found no evidence of outrageous conduct by the government agents, see id. at 1507 , and then remanded for a new trial consistent with its opinion, see id. at 1510 .

${ }^{97}$ See United States v. Brown, No. 94-1139, 1996 WL 283313, at *2 (1st Cir. Mar. 4, 1996) ("This [sentencing manipulation] claim has been recognized as theoretically valid, but has never been used in this circuit to reduce a defendant's sentence." (citations omitted)); United States v. Lacey, 86 F.3d 956, 963 (10th Cir. 1996) (stating that the Tenth Circuit has not directly addressed the sentencing manipulation issue, but that the outrageous governmental conduct defense is similar, and that that defense allows "sufficiently egregious government conduct" to "affect the sentencing determination"); United States v. Shipley, No. 95-1036, 1995 WL 442209, at *1 (8th Cir. July 27, 1995) ("A district court may depart downward under the Guidelines based on sentencing entrapment or sentencing manipulation."); United States v. Sivils, 960 F.2d 587, 598-99 (6th Cir. 1992) ("If Jordan could demonstrate that the government ma- 
and Eleventh Circuits have rejected the defense, ${ }^{98}$ while the remaining circuits have not yet addressed the issue. ${ }^{9}$

\section{Avoiding Confusion: Sentencing Entrapment and Sentencing Manipulation Distinguished}

These two defenses are easily confused. The confusion occurs largely because the same conduct can be viewed as either sentencing entrapment or sentencing manipulation. Take, for example, the conduct in United States $v$. Shepherd, discussed earlier. ${ }^{100}$ In that case, the defendant intended to sell powder cocaine but was induced to convert it to crack. ${ }^{101}$ Although the district court opinion did not indicate whether the defendant had argued sentencing entrapment or sentencing manipulation, the court did indicate, however, that both

nipulated the dollar amount of cocaine to increase his sentence, such manipulation would certainly provide a fundamental fairness defense against the higher sentence.").

${ }^{98}$ See Cotts v. United States, No. 95-2100, 1996 WL 397444 , at *1 (7th Cir. July 11, 1996) ("The defense of sentencing manipulation is a dead letter in this circuit."). The Eleventh Circuit's rejection of sentencing manipulation is less clear. In United States $v$. Miller, after noting the Eleventh Circuit's rejection of both the traditional entrapment defense and the sentencing entrapment defense, the court remarked that while the defendant argued that "there exists a distinction between sentencing entrapment and manipulation" the court could "see no difference in this context between entrapment and manipulation." See United States v. Miller, 71 F.3d 813, 818 \& n.2 (11th Cir. 1996). The court did, of course, leave open the possibility that in a different context it might distinguish sentencing entrapment and sentencing manipulation. See id. at 818 . But even if it did distinguish between the two sentencing defenses, after having rejected both the traditional entrapment defense and the sentencing entrapment defense, it is highly unlikely that the Eleventh Circuit would recognize sentencing manipulation.

${ }_{99}$ See United States v. Gomez, 103 F.3d 249, 256 (2d Cir. 1997) ("The status of sentencing manipulation in this circuit is unclear... . We need not decide today whether we recognize such a defense."); United States v. Kaczmarski, 939 F. Supp 1176, 1181 (E.D. Pa. 1996) (allowing a sentencing manipulation defense while noting that "[o]ur court of appeals has not addressed whether the sentencing factor manipulation doctrine ... is a viable one"); United States v. Moore, No. 95-5885, 1996 WL 452423, at *4 (4th Cir. Aug. 12, 1996) (stating that ${ }^{~}[\mathrm{t}]$ his court has not decided whether sentencing manipulation can ever justify a downward departure ${ }^{n}$ but noting that it would require proof of outrageous conduct); United States v. Tremelling, 43 F.3d 148, 151 (5th Cir. 1995) (" $[T]$ his court apparently has not expressly determined whether we have accepted the concept of 'sentencing factor manipulation.'"); United States v. Mitchell, No. 95-50583, 1996 WL 673867, at *2 (9th Cir. Nov. 7, 1996) ("Even if sentence manipulation is a viable doctrine, a question we do not decide, this court has rejected the claim that sentencing manipulation occurs whenever the government ... opts ... in favor of continuing its investigation.").

${ }^{100} 857$ F. Supp. 105 (D.D.C. 1994); see also supra notes $70-81$ and accompanying text.

101 See id. at 106. 
defenses were implicated in the case. ${ }^{102}$ The court believed the defendant could have argued for either one. In a sentencing entrapment claim, the defendant would have argued that she was predisposed only to sell powdered cocaine and not crack. Her sentence, therefore, should have been based on the type of drug she intended to sell, not the type she was entrapped into selling. In a sentencing manipulation claim, the defendant would have argued that the undercover agent had acted improperly by pressuring her to sell a type of drug she had not been inclined to sell when the sole reason for doing so was to increase her sentence. The overlap of the two doctrines is clearly seen in the court's own language. The court wrote:

The defendant, though predisposed to sell cocaine, was asked to cook the cocaine for the sole purpose of increasing her resulting sentence. Under such circumstances, this conduct is specifically designed to manipulate the sentence received by undermining the defendant's due process rights. This purpose and practice must be viewed as outrageous. Thus, both doctrines are implicated. ${ }^{10}$

This Comment, however, will distinguish the two defenses. Sentencing entrapment will refer to a claim based upon the defendant's lack of predisposition. Sentencing manipulation will refer to a claim based upon police misconduct.

\section{THE LEGAL THEORY OF SENTENCING ENTRAPMENT AND SENTENCING MANIPULATION}

While the courts have spent time explaining the need for the defenses and developing the terminology for the defenses, the courts have spent little time explaining each defense's underlying legal theory. The courts either remain silent or offer differing explanations. ${ }^{104}$

\footnotetext{
${ }^{102}$ See id. at 111.
}

${ }^{103}$ Id.

${ }^{104}$ See, e.g., United States v. Lacey, 86 F.3d 956, 962 (10th Cir. 1996) (suggesting sentencing manipulating should be considered under the "outrageous governmental conduct" standard but failing to explicitly adopt a sentencing manipulation defense); United States v. Egemonye, 62 F.3d 425, 426 (1st Cir. 1995) (stating that "where government agents have improperly enlarged the scope or scale of the crime, the sentencing court has power to exclude the tainted transaction" but offering no explanation regarding the legal basis for that standard (internal quotations omitted)); United States v. Barth, 990 F.2d 422, 424-25 (8th 1993) (holding that "sentencing entrapment may be legally relied upon to depart under the sentencing guidelines" but failing to explain the legal theory which allows such a departure); United States v. Shepherd, 857 F. Supp. 105, 111, 112 (D.D.C. 1994) (granting a downward departure because the government conduct had "undermin[ed] the defendant's due process rights"suggesting a constitutional basis for the departure-and because "the Judici- 
Since both sentencing defenses make claims similar to the traditional entrapment defense, this Comment begins the search for an underlying legal justification by examining the development of the traditional entrapment defense. An understanding of the legal authority on which the traditional entrapment defense was based may elucidate a court's present authority to establish new but similar defenses. UItimately, this Comment concludes that the theories offered to support the traditional entrapment defense do not support the adoption of either sentencing manipulation or sentencing entrapment defenses.

\section{A. Legal Underpinnings of the Entrapment Defense-Precursor to Sentencing Entrapment and Sentencing Manipulation}

While the entrapment defense is now thoroughly accepted, ${ }^{105}$ the Supreme Court's authority to adopt the traditional entrapment defense has been debated since the defense was first established. ${ }^{106}$ The Supreme Court first recognized the entrapment defense in Sorrells $v$. United States. ${ }^{107}$ In that case, a prohibition agent and a friend of Sor-

ary ...stand[s] as a bulwark against overreaching by law enforcement"-suggesting the court's supervisory authority as grounds for departure); see also United States v. Jones, 18 F.3d 1145, 1154 \& n.12 (4th Cir. 1994) (stating that the Fourth Circuit has not addressed the legal viability of sentencing entrapment and expressing no opinion as to whether Application Note 17 of the Sentencing Guidelines (Application Note 15 in the 1995 version of the Guidelines) accounts for the theories of sentencing manipulation and sentencing entrapment); United States v. Staufer, 38 F.3d 1103, 1107 (9th Cir. 1994) (basing a sentencing entrapment claim on Application Note 15). Application Note 15 is discussed in detail, infra, Part III.D.1.

${ }^{105}$ See Sara Sun Beale, Reconsidering Supervisory Power in Criminal Cases: Constitutional and Statutory Limits on the Authority of the Federal Courts, 84 COLUM. L. REV. 1433, 1519 (1984) ("Perhaps the entrapment defense itself has been legitimated by four decades of congressional acquiescence."); Jonathan C. Carlson, The Act Requirement and the Foundations of the Entrapment Defense, 73 VA. L. REV. 1011 , 1013 (1987) ("[S]ome version of the entrapment defense has been created by legislation or judicial decision in all fifty states.").

${ }^{106}$ See Fred Warren Bennett, From Sorrells to Jacobson: Reflections on Six Decades of Entrapment Latw, and Related Defenses, in Federal Court, 27 WAKE FOREST L. REV. 829, 833 (1992) (noting that United States v. Sorrells, 287 U.S. 435 (1932), the first Supreme Court case to adopt the entrapment defense, "sparked a heated debate" regarding the foundations of the entrapment defense); Carlson, supra note 105, at 1013 ("Courts and commentators still disagree over certain basic issues regarding the entrapment defense, including the reason for creating the defense .... and even whether the defense is part of the law of criminal procedure or the substantive criminal law."); Nancy Y.T. Hanewicz, Note, Jacobson v. United States: The Entrapment Defense and Judicial Supervision of the Criminal Justice System, 1993 WIS. L. REV. 1163, 1168 ("In all four [entrapment cases], the issue of the Court's authority to create the entrapment defense was pivotal.").

${ }^{107} 287$ U.S. 435 (1932). 
rells went to Sorrells's home where the agent introduced himself as a furniture salesman. ${ }^{108}$ During the conversation that followed, the agent asked Sorrells if Sorrells could supply him with liquor. ${ }^{109} \mathrm{At}$ first, Sorrells told the agent that he "did not fool with whiskey." "110 But after further requests, Sorrells left and returned some time later with the liquor. ${ }^{111}$ The agent paid Sorrells five dollars for the liquor. ${ }^{112}$

Eight of the nine Justices ruled that Sorrells had been entrapped. ${ }^{113}$ Those eight Justices split five to three, however, regarding the definition of entrapment and the basis for the Court's authority to establish the defense. ${ }^{114}$

\section{The Majority Approach: Legislative Intent Underlies the Entrapment Defense}

The Sorrells majority found entrapment because Sorrells had not been predisposed to sell liquor. ${ }^{115}$ The Court found that "the defendant had no previous disposition to commit [the offense] but was an industrious, law-abiding citizen, and that the agent lured defendant, otherwise innocent, to [commit the offense] by repeated and persistent solicitation." ${ }^{\text {116 }}$ Thus the majority looked at the intentions of the defendant, found that absent the government conduct the defendant would not have committed the crime, and declared him entrapped. This approach, which bases a defendant's access to the entrapment defense upon the defendant's state of mind, is called the "subjective" approach. $^{117}$

In finding that the defendant was entrapped, and therefore immune from prosecution, the majority was careful to explain that it was

${ }^{108}$ See id. at 440 .

${ }^{109}$ See id. at 439 . The number of times the agent asked for liquor was never clearly established. See id.

${ }^{110} I d$. at 440.

111 See id. at $439-40$ (contrasting the government's claim that the defendant left his home and came back after "a few minutes," with defense witnesses who stated that the trip took "twenty to thirty minutes").

112 See id. at 439.

113 See id. at 453,459 .

${ }^{114}$ See id. at 441 ("[B] ut the question whether [the agent's conduct] precludes prosecution ... [and] upon what theory, has given rise to conflicting opinion.").

${ }^{115}$ See id.

${ }^{116} I d$.

${ }^{117}$ See Bennett, supra note 106, at 834 ("The subjective test of entrapment ... focuses exclusively on the defendant's predisposition ...."); Hanewicz, supra note 106, at 1177-78 ("The [majority] approach is labelled 'subjective' because it centers upon the state of mind (or predisposition) of the defendant."). 
not undoing legislation ${ }^{118}$ or putting forth new public policy. ${ }^{119}$ Both functions would be outside the domain of the judiciary. Rather, the majority kept to the traditional function of the judiciary, which is to construe statutes as they are written by the legislature. ${ }^{120}$ The majority claimed that the legislature did not intend that an "otherwise innocent" defendant should be prosecuted. ${ }^{121}$ By narrowly construing the legislative intent, the majority excluded the defendant from the impact of the statute. In the decades that followed the Sorrells decision, in Sherman v. United States, ${ }^{122}$ United States v. Russell, ${ }^{129}$ and Jacobson $v$. United States, ${ }^{124}$ the Supreme Court consistently upheld the subjective approach and its foundation in legislative intent.

\section{Criticism of the Majority Approach}

Criticism of the subjective approach began the moment the Sorrells decision was decided. In his concurring opinion in Sorrells, Justice Roberts described the majority decision as "strained and unwarranted." Since then, critics of the subjective approach have questioned whether in fact Congress intended to exclude nonpredisposed defendants from the scope of all criminal statutes. ${ }^{126}$ Jus-

118 See Sorrells, 287 U.S. at 450 (“Judicial nullification of statutes, admittedly valid and applicable, has, happily, no place in our system.").

See id. at 445-46 ("To the suggestion of public policy the objectors answer that the legislature, acting within its constitutional authority, is the arbiter of public policy and that, where conduct is expressly forbidden and penalized by a valid statute, the courts are not at liberty to disregard the law and to bar a prosecution .... It is manifest that these arguments rest entirely upon the letter of the statute." (citation omitted)).

See id. at 450 ("We conceive it to be our duty to construe the statute here in question reasonably, and we hold that it is beyond our prerogative to give the statute an unreasonable construction ....").

${ }_{121}$ See id. at 448 (stating that the Court was "unable to conclude that it was the intention of the Congress in enacting this statute that its processes of detection and enforcement should be abused" for the purpose of luring someone "otherwise innocent" to the commission of a crime).

122356 U.S. 369, $372-73$ (1958) ("The principles by which the courts are to make this determination [whether entrapment has been established] were outlined in Sorrells.").

${ }^{123} 411$ U.S. 423, 433 (1973) ("This Court's opinions in Sorrells... and Sherman... held that the principal element in the defense of entrapment was the defendant's predisposition to commit the crime.... We decline to overrule these cases.").

124503 U.S. 540, 549 n.2 (1992) (upholding the subjective approach). But see Hanewicz, supra note 106, at 1166 (claiming that the Jacobson decision supported Sorrells in name only while actually applying objective criteria).

${ }^{125}$ Sorrells, 287 U.S. at 456 (Roberts, J., concurring).

${ }^{126}$ Commentators have also criticized the subjective approach because the proof 
tice Frankfurter in his concurring opinion in Sherman argued that the only possible intention one could draw from the statute was that the legislature intended to criminalize exactly the conduct in which the entrapped defendant had engaged. ${ }^{127} \mathrm{He}$ explained that "[a] statute prohibiting the sale of narcotics is as silent on the issue of entrapment as it is on the admissibility of illegally obtained evidence." ${ }^{128} \mathrm{He}$ concluded that the Sorrells finding of a legislative intent was "sheer fiction. ${ }^{129}$ Commentators since have followed suit. ${ }^{130}$

\section{The Minority Approach: Supervisory Authority Permits the Adoption of the Entrapment Defense}

Legislative intent is not the only rationale offered to support the entrapment defense. A persistent minority on the Supreme Court has defined and rationalized the entrapment defense differently. In his concurring opinion in Sorrells, Justice Roberts asserted that the true purpose of the entrapment defense is to discourage indecent police practices. ${ }^{131}$ This view of the entrapment defense is called the "objective" approach. The objective approach examines only the conduct of law enforcement and ignores the state of mind of the defendant. ${ }^{132}$ If the police activity would have induced an average law-

of non-predisposition rests on the defendant's reputation and prior behavior rather than the facts of the case. See, e.g., Sorrells, 287 U.S. at 459 (Roberts, J., concurring) ("The [subjective approach] ... pivots conviction in such cases, not on the commission of the crime charged, but on the prior reputation ... of the defendant."); Carlson, supra note 105, at 1039 (arguing that the subjective approach "authorizes an 'open season' on any person who could be shown in a court of law-through proof of prior crimes ... bad reputation, or ... bad character-to have a propensity to engage in crime"). This criticism, which does not attack the validity of the foundation of the defense, is outside the scope of this Comment.

${ }^{127}$ See Sherman, 356 U.S. at 379 (Frankfurter, J., concurring in the result).

128 Id. at 381.

129 Id. at 379.

${ }^{130}$ See, e.g., United States v. Russell, 411 U.S. 423, 442 (1973) (Stewart J., dissenting) ("The very fact that he has committed [the crime] demonstrates conclusively that he is not innocent of the offense."); PAUL MARCUS, THE ENTRAPMENT DEFENSE 65 (1989) ("Could there be a Congressional 'state of mind' on a silent issue?"); Carlson, supra note 105, at 1019 ("An entrapped defendant, after all, has acted in a manner deemed criminal by the legislature. This fact would appear to provide ample reason to incarcerate him.").

${ }^{131}$ See Sorrells, 287 U.S. at $454-55$ ("There is common agreement that where a law officer envisages a crime, plans it, and activates its commission ... the consummation of so revolting a plan ought not to be permitted by any self respecting tribunal.... Public policy forbids such sacrifice of decency.").

${ }_{132}$ See Bennett, supra note 106, at 837 ("[T] the actions taken by law enforcement ... "); Hanewicz, supra note 106, at 1178 ("The 
abiding citizen to commit the crime, then the defendant is said to be entrapped and cannot be prosecuted. ${ }^{133}$ As Justice Frankfurter explained in his concurring opinion in Sherman, "[ $t$ ]he crucial question ... is whether the police conduct... falls below standards, to which common feelings respond, for the proper use of governmental power." 134

In Sorrells and its progeny, the minority based its entrapment defense on the right of the Court to preserve its own integrity. ${ }^{135}$ At the time of Sorrells, the Court was still arguing over the extent of its authority to control the administration of criminal justice in the courts. ${ }^{136}$ In 1943, however, in McNabb v. United States, ${ }^{197}$ the Supreme Court announced that one of the inherent powers of the judiciary is to "establish [] and maintain [] civilized standards of procedure and evidence." 198 This authority would come to be known as the Court's supervisory authority. Hence, by the time Sherman was decided in 1958, the Court had already established that the Court's supervisory authority encompassed the ability to apply "proper standards for the enforcement of federal criminal law in the federal courts." ${ }^{139}$ Thus, the minority was able to rely explicitly on the Court's supervisory authority to justify the entrapment defense. ${ }^{140}$ Since Sherman, the mi-

objective approach ... regards entrapment as a means of controlling police conduct without reliance on the character of the defendant.").

${ }^{193}$ Bennett, supra note 106, at 836 ("According to the objective test, if the method of encouragement used was likely to induce an ordinary law-abiding citizen to commit the offense, then the case should be dismissed."); Hanewicz, supra note 106, at 1179 ("If the seductions offered by the government would have induced a reasonable, lawabiding citizen to commit the crime, the defendant should be acquitted ....").

134 Sherman, 356 U.S. at 382.

195 See, e.g., Sorrells, 287 U.S. at 457 (Roberts, J., concurring) ("The [entrapment] doctrine rests... on a fundamental rule of public policy. The protection of [a court's] own functions and the preservation of the purity of its own temple belong only to the court.").

${ }_{196}$ See Carlson, supra note 105, at 1026 ("At the time of the Sorrells case, the Court was preoccupied with a dispute over the Court's power to control the general administration of criminal justice in the federal courts.").

1978 U.S. 332 (1943).

${ }^{133}$ Id. at 340; see also Beale, supra note 105, at 1435 ( $" M c N a b b$ v. United States... is generally regarded as the first supervisory power decision."); Hanewicz, supra note 106, at 1166 ("Entrapment was adopted by the Supreme Court before the Court articulated its doctrine of judicial supervision." (citation omitted)).

139 McNabb, 318 U.S. at 341.

${ }^{140}$ See Sherman v. United States, 356 U.S. 369, 380 (1958) (Frankfurter, J., concurring in the result) (describing the federal courts' obligation to "set their face against enforcement of the law by lawless means" and citing $M c N a b b$ as its authority). Other proponents draw on the same language Justice Brandeis used in Casey v. United States, 
nority view which supports the objective defense has relied on the Court's authority to uphold proper standards. ${ }^{141}$

\section{Criticism of the Minority Approach}

The objective approach, however, has not escaped criticism. Criticism of the objective approach rests largely on whether the Court in fact possesses its self-declared supervisory authority. The Court first established its supervisory authority in $M c N a b b$ v. United States. ${ }^{142}$ There, the Supreme Court excluded two murder confessions after the defendants were held for two days and repeatedly questioned without any contact with family, friends or counsel. ${ }^{143}$ Holding the defendants for two days was contrary to federal law which required that the men be arraigned promptly. ${ }^{144}$ The fact that the police had failed to arraign the men, however, should not have been grounds for excluding the confessions. As the dissent indicated, prior to $M c N a b b$, a confession was admissible so long as it was given voluntarily. ${ }^{145}$ In fact, the majority admitted that the use of confessions obtained in this manner was not contrary to law. ${ }^{146}$

Nevertheless, the $M c N a b b$ Court excluded the confessions on the basis that, were the Court to admit the evidence, the Court would be-

276 U.S. 413,425 (1928), to argue for the Court's supervisory authority to support the entrapment defense. See United States v. Russell, 411 U.S. 423, 442-43 (1973) (Stewart, J., dissenting) (citing Brandeis's argument that a prosecution should be stopped "in order to protect the Government. To protect it from illegal conduct of its officers. To preserve the purity of its courts."); see also Beale, supra note 105, at 1443 (describing Justice Brandeis's arguments supporting the court's supervisory authority); Note, The Judge-Made Supervisory Power of the Federal Courts, 53 GEO. L.J. 1050, 1067-69 (1965) [hereinafter Judge-Made Supervisory Power] (noting the minority's reliance on the Court's supervisory authority as a basis for the entrapment defense).

${ }^{141}$ See Russell, 411 U.S. at $442-43$ (Stewart, J., dissenting) (arguing that the purpose of the entrapment defense is to "prohibit unlawful governmental activity ... and to preserve the purity of [the] courts" (internal quotations omitted)).

142318 U.S. 332 (1943).

149 See id. at 341 ("Quite apart from the Constitution, therefore, we are constrained to hold that the evidence elicited from the petitioners in the circumstances disclosed here must be excluded.").

${ }^{144}$ See id. at 341-44 (pointing to a variety of federal and state statutes "requiring that the police must with reasonable promptness show legal cause for detaining arrested persons").

${ }_{145}$ See id. at 348 (Reed, J., dissenting) ("Statements made while under interrogation may be used at a trial if it may fairly be said that the information was given voluntarily.").

${ }^{46}$ See id. at 345-46 ("[W]e have no specific provisions of law governing federal law enforcement officers in procuring evidence from persons held in custody."). 
come an "accomplice[] in willful disobedience of the law." ${ }^{147}$ The Court, one commentator noted, believed that it had a "duty to prevent such corruption of the federal judiciary" through the use of tainted evidence. ${ }^{148}$ Thus, beginning with $M c N a b b$ and in cases that followed, the Supreme Court's supervisory authority has included the Court's right to regulate and modify improper police behavior. ${ }^{149}$

Some commentators have argued that the Court's authority to regulate police conduct has no valid legal foundation. ${ }^{150}$ All federal courts are courts of limited jurisdiction. ${ }^{151}$ Thus a federal court's authority must be derived from the Constitution, a statute-such as a rules enabling act-or inherent powers of a court. ${ }^{152}$ Examining these sources one by one, these commentators conclude that the Court's supervisory authority has no legitimate source. First, they argue, "Article III of the federal constitution contains no explicit grant of supervisory jurisdiction." ${ }^{\text {153 }}$ And certainly, the Constitution does not direct the judiciary to oversee the conduct of the executive branch. ${ }^{154}$ As for statutes, Congress has passed several rules enabling acts which

147 Id. at 345.

149 Judge-Made Supervisory Power, supra note 140, at 1064

149 See Office of Legal Policy, Department of Justice, Repont to the Attorney General on the Judiciary's Use of Supervisory Power to Control Federal Lazv Enforcement Activity, 'Truth in Criminal Justice' Report No. 5, 22 U. MICH. J.L. REFORM 773, 795 n.62 (1989) [hereinafter Report to the Attorney General] (listing cases in which the courts have used their supervisory authority to exclude evidence tainted by law enforcement's out-ofcourt misconduct).

${ }^{150}$ Judge-Made Supervisory Power, supra note 140, at 1077 (stating that the foundations of a court's supervisory power "cannot confidently be traced to any identifiable sourcen).

151 See Northwest Airlines, Inc. v. Transport Workers Union, 451 U.S. 77, 95 (1981) ( $[\mathrm{F}]$ ederal courts, unlike their state counterparts, are courts of limited jurisdiction that have not been vested with open-ended lawmaking powers.").

${ }^{152}$ See Beale, supra note 105, at 1506 (considering the potential sources of power of the courts as deriving from the Constitution, federal statute, areas of special judicial competence, and their authority to create federal common law); Report to the Attorney General supra note 149, at 785-86 ("If the federal judiciary has any supervisory authority, this authority must have its source either in the Constitution or in Act of Congress.... [The only remaining source of power is an] inherent or implied aspect of Article III."); Judge-Made Supervisory Power, supra note 140, at 1051 (listing the same three sources of a court's authority).

${ }_{153}$ Judge-Made Supervisory Power, supra note 140, at 1051.

See Report to the Attorney General, supra note 149, at 785 (“[N] either Article III nor any other provision of the Constitution expressly authorizes the courts to oversee the administration of justice in the federal system ...."); id. at 816 ("[T] he imposition of judicially fashioned standards for the conduct of investigations is but an unwarranted arrogation of the power entrusted by the Constitution to the legislative and executive branches."). 
allow the Court to establish rules of procedure. ${ }^{155}$ These enabling acts permit the Court to promulgate standardized, written rules. The enabling acts do not, however, grant the Court the power to establish new rules on a case-by-case basis. ${ }^{156}$ For example, the exclusionary rule established in $M c N a b b$ falls outside the province of any rules enabling act because it arose from the specific facts of a particular case rather than from a standardized rulemaking process that Congress had authorized.

The only other prong upon which the Court's supervisory authority might rest is its inherent or implied powers. The Court's inherent powers are those that are necessary for the Court to function. ${ }^{157}$ History contradicts the argument that rulemaking is necessary for the Court to function. Beginning with the Judiciary Act in 1789, Congress regulated courtroom procedure. ${ }^{158}$ Thus, Congress viewed formulating rules of procedure as a legislative function. ${ }^{159}$ And, significantly, so did the Supreme Court. In an early opinion upholding the adoption of a procedural rule by a federal district court, the Supreme Court held the adoption valid only because Congress had delegated its authority to the federal courts. ${ }^{160}$ Thus, neither Congress nor the Court viewed the authority to establish procedural rules as inherent to the judiciary.

A less extreme criticism accepts a limited recognition of the Court's supervisory authority but denies that the Court's supervisory authority extends to regulating out-of-court police conduct. A limited

${ }^{155}$ See, e.g., Rules Enabling Act of 1934, Pub. L. No. 73-415, 48 Stat. 1064 (current version at 28 U.S.C. $\$ 2072$ (1994)); see also Judge-Made Supervisory Power, supra note 140, at 1051 (noting that the Enabling Act of 1934 authorized the Supreme Court to promulgate the Federal Rules of Civil Procedure).

${ }_{156}$ See Report to the Attorney General, supra note 149, at 785 ("Congress has never empowered the judiciary to exercise [supervisory] authority."); Judge-Made Supervisory Power, supra note 140, at 1051 (arguing that the mere fact that some state supreme courts have the power to establish new rules on a case-by-case basis does not mean that federal courts can also do so).

${ }^{157}$ See Report to the Attorney General, supra note 149, at 788 ("[C]ourts must have certain powers if they are to function as courts."); Judge-Made Supervisory Power, supra note 140 , at 1052 ("Inherent power has been defined as that which is essential to the existence, dignity and functions of the court as a constitutional tribunal and from the very fact that it is a court ...." (internal quotations omitted)).

${ }_{138}$ Judiciary Act, Sept. 24, 1789, 1 Stat. 73 (codified as amended at 18 U.S.C. $\$ 3041$ (1994)).

${ }^{159}$ See Report to the Attomey General supra note 149, at 787 (arguing that establishing rules and procedures is not "inherently and exclusively a judicial function").

${ }^{160}$ See Wayman v. Southard, 23 U.S. (10 Wheat.) 1, 14-15 (1825) (cited in Report to the Attorney General, supra note 149, at 787). 
recognition of the Court's supervisory authority rests on the Court's implied powers and time. It acknowledges that "it is helpful and in some instances necessary" for the Court to adopt procedural rules. ${ }^{161}$ Furthermore, the Court's "special competence in dealing with technical matters of the litigation process" makes it best suited to formulate these necessary rules. ${ }^{162}$ Time also validates the Court's use of its supervisory authority. In the fifty-three years since $M c N a b b$, the Supreme Court has been using supervisory authority as a basis of opinion. In only two instances has Congress acted to overrule the Supreme Court. ${ }^{163}$ If only through time and acquiescence, the Courts' use of supervisory authority has gained legitimacy. ${ }^{164}$

This limited recognition of the Court's supervisory authority does not, however, countenance the adoption of rules that regulate the conduct of law enforcement outside the courtroom. ${ }^{165}$ Such rules exceed the scope of the Court's supervisory authority. The Court's "special competence regarding technical matters of judicial administration provides no justification" for regulating out-of-court conduct. $^{166}$ Recently, the Supreme Court has recognized this limited interpretation of the Court's supervisory authority. In its 1992 decision United States $v$. Williams, the Supreme Court held that a court's supervisory authority should not be used to dictate prosecutorial conduct outside the courtroom. ${ }^{167}$

${ }^{161}$ Beale, supra note 105 , at 1475.

162 Id.

${ }^{163}$ See id. at 1454. One commentator suggests that rulemaking authority has traditionally been a shared function, not the sole prerogative of the legislature. See JudgeMade Supervisory Power, supra note 140, at 1054 ("[T] he argument over who had the power to adopt uniform rules of procedure for the district courts was resolved pragmatically by co-action of the legislature and the judiciary....").

164 See Judge-Made Supervisory Power, supra note 140, at 1056.

165 See Beale, supra note 105, at 1494 ("Although many supervisory power decisions fit comfortably within the scope of the [federal courts'] authority,... other decisions ... cannot be so justified."); Judge-Made Supervisory Power, supra note 140, at 1077 ("Some of the supervisory power decisions ... [are] fairly compatible with traditional notions of judicial power.... But other recent applications of supervisory power, notably the jury composition cases and the $M c N a b b$ line of cases, represent a distinct departure from what courts have traditionally done. Moreover,... the authority for the latter type cannot confidently be traced to any identifiable source.").

166 Beale, supra note 105 , at 1494.

167 See United States v. Williams, 504 U.S. 36, 46-47 (1992) ("We did not hold ... that the courts' supervisory power could be used, not merely as a means of enforcing or vindicating legally compelled standards of prosecutorial conduct ... but as a means of prescribing those standards of prosecutorial conduct in the first instance-just as it may be used as a means of establishing standards of prosecutorial conduct before the courts themselves."). 
Whether the criticisms are levied against the subjective or objective versions of the entrapment defense, the Court's original authority to establish the defense was questionable. The subjective entrapment defense derives from a legislative intent that may or may not have existed. The objective entrapment defense relies on the Court's supervisory authority, which may not extend to the creation of rules regulating the executive branch. These questions regarding the Court's authority to establish the entrapment defenses are equally applicable to a lower court's authority to establish a sentencing defense. Before turning to the question of a lower court's authority to establish sentencing defenses, however, another defense-one related to the objective entrapment defense-must be considered.

\section{B. Outrageous Government Conduct: A Constitutional Defense}

While the objective approach has never garnered enough votes on the Court to supersede the subjective approach, it did give rise to a similar defense whose legal validity is not questioned. In 1973, in United States $v$. Russell, ${ }^{168}$ the Court refused to recognize the objective approach, but acknowledged that "we may some day be presented with a situation in which the conduct of law enforcement agents is so outrageous that due process principles would absolutely bar the government from invoking judicial processes to obtain a conviction."

The "outrageous government conduct" defense is similar to the objective entrapment defense in that it focuses on the conduct of law enforcement agents. ${ }^{170}$ The most significant difference, however, is that the outrageous government conduct defense is grounded in the Constitution $^{171}$ whereas the objective entrapment defense is grounded in the Court's supervisory authority. ${ }^{172}$

\section{Sentencing Entrapment and Sentencing Manipulation: Following in the Footsteps of Entrapment}

Sentencing entrapment and sentencing manipulation parallel the

168411 U.S. 423 (1973).

IC9 Id. at 431-32.

170 See Bennett, supra note 106, at 858 ("[T] he defense of outrageous governmental conduct focuses exclusively on the government's actions.").

${ }^{171}$ See id. ("[T] he due process defense of outrageous governmental conduct is one of constitutional dimension.").

${ }^{172}$ See supra notes $132-41$ and accompanying text. 
theories underlying the entrapment defense. ${ }^{173}$ Sentencing entrapment follows the path laid out by the subjective entrapment defense. The subjective entrapment defense claims that because the defendant lacked a predisposition to commit the crime, she should not be prosecuted. Sentencing entrapment admits that the defendant was predisposed to commit a criminal act but denies that the defendant was predisposed to commit as serious a crime as the one with which she is now being charged. Both defenses rely on the defendant's state of mind-one to justify eliminating punishment, the other to mitigate it.

Sentencing manipulation follows the objective entrapment defense and the outrageous government conduct defense. Both the objective entrapment defense and the outrageous government conduct defense protect a defendant from prosecution in the event of police misconduct. Similarly, sentencing manipulation focuses on police misconduct as a rationale for mitigating a defendant's sentence. Some courts recognizing sentencing manipulation have followed the constitutional standard outlined in Russell and required outrageous government conduct to justify a downward departure at sentencing. ${ }^{174}$ Other courts have required only a showing of improper conduct. ${ }^{175}$ Presumably, a court adopting the improper conduct standard does so pursuant to its supervisory authority."

The final similarity between the traditional entrapment defense and the new sentencing defense is that theoretical questions remain about each defense's proper legal foundations. The difference between the entrapment defense and the sentencing defenses is that, despite theoretical questions regarding its legal underpinnings, the entrapment defense has been accepted for over sixty years. ${ }^{177}$ Since

${ }^{173}$ The sentencing defenses are now following an identical developmental path as the entrapment defense did fifty years ago. In both instances, political and legal developments gave rise to abusive police tactics. Where Prohibition preceded the entrapment defense, the Federal Sentencing Guidelines preceded the sentencing defenses. Ultimately, the courts became concerned about the tactics and began considering new defenses. The one difference between the development of the traditional entrapment defense and the sentencing defenses is that with the traditional entrapment defense, the courts were much more explicit about debating their authority to establish the new defense. No such debate has occurred with sentencing defenses.

174 See infra note 205 and accompanying text.

175 See infra notes 208-10 and accompanying text.

176 See infra note 211 and accompanying text.

177 The subjective approach was adopted by the Supreme Court in United States $v$. Sorrells, 287 U.S. 435 (1932). The objective approach has since been adopted by many states and the Model Penal Code. See MODEL PENAL CODE $\S 2.13$ (1980); Bennett, su- 
Congress has not acted to restrict or eliminate it, the defense has gained legitimacy. ${ }^{178}$ Sentencing defenses, however, have not yet been legitimated by the passage of time. Sentencing entrapment and sentencing manipulation are still less than a decade old and have not yet been acknowledged by the Supreme Court. As courts across the country recognize both sentencing entrapment and sentencing manipulation, it is appropriate to ask now, at the outset, whether either defense rests on a solid legal foundation.

\section{The Lower Courts' Authority to Adopt Sentencing Entrapment}

Sentencing entrapment, which focuses on the defendant's predisposition, follows the subjective approach. The subjective approach relies on the theory that Congress did not intend to criminalize a non-predisposed defendant. Thus the validity of sentencing entrapment will rest on the finding of a legislative intent to decrease the punishment of less culpable defendants. Appropriately, when the Ninth Circuit in United States v. Staufer granted a downward departure based on a sentencing entrapment claim, it looked to the Sentencing Guidelines to support the defense. ${ }^{179}$ This Section will discuss the Ninth Circuit's interpretation of Application Note 15 to the Sentencing Guidelines and the difficulty of otherwise using legislative intent as a basis for a sentencing entrapment defense.

\section{Application Note $15^{180}$ as a Foundation for Sentencing Entrapment}

In United States v. Staufer, described above, the defendant was arrested when he agreed to sell 10,000 doses of LSD when he had originally offered to sell only 5000 doses. ${ }^{181}$ The Staufer court relied on Application Note 15 which was added in 1993, one year prior to Staufer. Application Note 15 reads:

\footnotetext{
pra note 106, at $835 \mathrm{nn} .37 \& 38$.

${ }^{178}$ See Beale, supra note 105, at 1519 ("Perhaps the entrapment defense itself has been legitimated by four decades of congressional acquiescence.").

179 See United States v. Staufer, 38 F.3d 1103, 1107 (9th Cir. 1994).

${ }^{180}$ The text of Application Note 15 was first introduced in the 1994 Sentencing Guidelines Manual as Application Note 17. See U.S. SENTENCING GUIDELINES MANUAL § 2D1.1 Application Note 17 (1994). In 1995, however, the same text appears under Application Note 15. See U.S. SENTENCING GuIDELINES MANUAL § 2D1.1 Application Note 15 (1995). Some earlier cases or texts may therefore refer to Application Note 17 instead of Application Note 15. See, e.g., United States v. Jones, 18 F.3d 1145, 1154 \& n.12 (4th Cir. 1994). The text of the two application notes are identical.

${ }^{181}$ See Staufer, 38 F.3d at 1105.
} 
If, in a reverse sting (an operation in which a government agent sells or negotiates to sell a controlled substance to a defendant), the court finds that the government agent set a price for the controlled substance that was substantially below the market value of the controlled substance, thereby leading the defendant's purchase of a significantly greater quantity of the controlled substance than his available resources would have allowed him to purchase except for the artificially low price set by the government agent, a downward departure may be warranted. ${ }^{182}$

Application Note 15 does not actually apply to the facts of Staufer. Application Note 15 requires that the defendant be caught in a reverse sting operation. A reverse sting occurs when the government agent is the seller and the defendant the buyer. ${ }^{183}$ Staufer was selling to, not buying from, an undercover agent. ${ }^{184}$ This is a straight sting. Furthermore, while the court found that the undercover agent offered more money in exchange for more doses of LSD, the court did not find that the agent had offered an "artificially" high price. ${ }^{185}$

Nonetheless, by generalizing the language of Application Note 15, the Staufer court found a legislative intent to justify a downward departure. The Staufer court argued that under Application Note 15, the Sentencing Commission had "expressly" recognized that government agents should not be allowed to structure any undercover operations so as purposely to increase a defendant's sentence. ${ }^{186}$ The court further concluded that Application Note 15 indicated Congress's intent that courts should consider a defendant's predisposition and capacity to engage in the transaction for which she is being charged. ${ }^{187}$ The court explained that while the application note referred to only one type of transaction, the note indicated the Sentencing Commission's awareness of "the unfairness and arbitrariness" of undercover agents who pressure defendants in order to increase a defendant's sentence. ${ }^{188}$

182 U.S. SENTENCING GUIDELINES MANUAL § 2D1.1 Application Note 15 (1995).

${ }^{183}$ See id.

${ }^{184}$ See Staufer, 38 F.3d at 1105.

${ }^{185}$ See id. ("There also is evidence that the CI [confidential informant] and Daul [the undercover agent] immediately offered to pay more money than they initially had agreed to pay when Staufer expressed reluctance at the larger deal.").

${ }^{186}$ See id. at 1107 ("[T] he Sentencing Commission now expressly recognizes that law enforcement agents should not be allowed to structure sting operations in such a way as to maximize the sentences imposed on defendants ....").

${ }^{187}$ See id. ("[T] he Sentencing Commission now expressly recognizes that ... courts may take into consideration the predisposition and capacity of the defendant to engage in a deal of the magnitude for which he or she was convicted.").

${ }^{188} I d$. 
The Staufer court gave a broad reading to the application note that may not be warranted. As the Staufer court recognized, the application note refers to only one type of undercover operation-a reverse sting. ${ }^{189}$ The Commission's intentions are unknown since its drafting sessions are not recorded and the Commission provides no legislative history. ${ }^{190}$ It is just as plausible, however, that the narrow language of the application note is due to the fact that either the Commission has not considered other types of manipulative behavior or that it has considered other types of manipulative behavior and expressly limited downward departures to the one practice described in the note. ${ }^{191}$ One court has interpreted Application Note 15 more narrowly. In United States $v$. Stavig, ${ }^{102}$ the Eighth Circuit upheld a district court's finding that Application Note 15 did not apply because the defendant "did not receive a larger quantity of cocaine due to a lower price." Rather, the agents fronted drugs for a "favorable" price. ${ }^{194}$ If one accepts that the Staufer interpretation is overbroad, the question remains whether courts have the authority to establish a general sentencing entrapment defense outside the Sentencing Guidelines.

\section{Legislative Intent as a Foundation for Sentencing Entrapment}

The establishment of a new sentencing entrapment defense based on legislative intent is, however, subject to the very criticisms aimed at the traditional entrapment defense. The traditional entrapment defense, based on legislative intent, is critiqued as "strained and unwarranted" because there is no evidence that Congress intended to exclude from prosecution non-predisposed defendants. ${ }^{105}$ Similarly, no evidence exists that the Sentencing Commission intended to limit the scope of punishment because the defendant intended to commit a

${ }^{189}$ See id. ("The Sentencing Commission's determination that the defendant may receive a downward departure when the government artificially lowers the price of the drugs, however, only addresses one of the ways in which drug enforcement agents are able to manipulate sentences.").

${ }^{190}$ Telephone Interview with Michael Courlander, Public Information Specialist, United States Sentencing Commission (Apr. 16, 1997).

${ }^{191}$ See Johnson, supra note 15 , at 218 (stating that if the Commission had intended to condemn all manipulations, then one would expect the amendment "to have been written more broadly").

${ }_{192}^{190} 80$ F.3d 1241 (8th Cir. 1996).

193 Id. at 1246.

194 Id. at 1244.

${ }^{195}$ See supra notes $125-30$ and accompanying text. 
lesser crime. As such, a sentencing entrapment defense resting on legislative intent would be equally "strained and unwarranted."

The Commission was not overly concerned that punishment reflect a defendant's blameworthiness. If anything, the Sentencing Commission seemed particularly unconcerned about an individual's particular culpability or predisposition. As mentioned above, Congress initially recommended that a judge consider, among other things, a "defendant's ... mental and emotional condition, ... family ties and responsibilities, community ties, role in the offense, criminal history, and dependence upon criminal activity for a livelihood, ${ }^{196}$ as well as the defendant's intent and purpose in committing the crime. ${ }^{197}$ The Commission, however, found that only three factors were relevant to sentencing: (1) a defendant's past criminal history; (2) her dependence upon the criminal activity for her livelihood; and (3) her acceptance of responsibility for the crime. ${ }^{198}$ In 1989, the Commission deleted the requirement that judges consider a defendant's motives, deeming it "unnecessary." ${ }^{199}$ The Sentencing Guidelines is a quantity-based sentencing scheme where the subjective characteristics of the defendant have little if any role to play. ${ }^{200}$ Claiming that it is the Commission's intent to exclude non-predisposed defendants from the scope of the Sentencing Guidelines would be, once again, "sheer fiction.","01

In his concurring opinion in Sorrells, Justice Roberts made a basic point that is as equally applicable now as it was then. He stated that the only possible intention one could draw from the criminal statute

196 See Ogletree, supra note 32, at 1953.

197 See Weinstein \& Bernstein, supra note 33, at 121.

198 See Ogletree, supra note 32, at 1953.

199 See supra note 35 and accompanying text.

200 See Johnson, supra note 15, at 205 ("The Guidelines... make[] harm to society the determinative factor in sentencing.").

${ }^{201}$ Sherman v. United States, 356 U.S. 369, 379 (1958) (Frankfurter, J., concurring in the result). The Guidelines state that a philosophical question arose whether punishment should be "scaled to the offender's culpability" or to "deterring others or incapacitating the defendant" and claim that no decision between the two philosophies was made. See U.S. SENIENCING GuIDELINES MANUAL 3 (1995). Nonetheless, the resulting structure of the Guidelines does not allow any consideration for a defendant's culpability. As the Guidelines explain, "[t] he larger the number of sub-categories of an offense and offender characteristics included in the guidelines, the greater the ... number of decisions required... [and] the greater the risk that different courts would apply the guidelines differently. . . thereby reintroducing the very disparity that the guidelines were designed to reduce." Id. Thus the Guidelines chose to value similarity in sentences over sentences scaled to a defendant's culpability. See Johnson, supra note 15, at 206. 
is that the legislature intended to criminalize exactly the conduct the defendant had engaged in. ${ }^{202}$ So too here, the only possible intention that one can draw from the Sentencing Guidelines is that Congress intended to punish individuals who committed criminal activity. Punishment is the point of the statute.

The judges and commentators who wish to establish sentencing entrapment as a defense and escape the punishment otherwise imposed by the Sentencing Guidelines are moved by the fact that the defendant is not truly culpable to the extent to which she is being punished. If this-punishment uncorrelated to blame-is the ill a judge wishes to correct, and if the judge wishes to base the defense on legislative intent, she will have to show that the Commission intended to correlate punishment to blameworthiness. This is a difficult showing to make.

If sentencing entrapment is nonetheless recognized by the courts, such as it was in Staufer, and neither the Sentencing Commission nor Congress moves to overturn it, time may still legitimize the defense. This, of course, would require the courts to reach beyond their own authority and claim justification through congressional and administrative silence.

\section{E. The Courts' Authority to Adopt Sentencing Manipulation}

While the sentencing entrapment defense responds to the concern that defendants are being punished disproportionately to their blameworthiness, the sentencing manipulation defense responds to the concern that the police are acting improperly. Sentencing manipulation is thus a descendant of the objective approach, as both amount to a claim that a defendant should not be punished due to police misconduct. At first, a sentencing manipulation claim was predicated upon outrageous government conduct-that is, a constitutional violation. ${ }^{203}$ While a constitutional violation offers a valid foundation to overturn a sentence, predicating a sentencing defense on a constitutional violation may not provide the remedy sought. More recently, the First Circuit has adopted a definition of sentencing ma-

${ }^{202}$ See United States v. Sorrells, 287 U.S. 435, 456 (1932) (Roberts, J, concurring) ("It cannot be said that entrapment excuses [the defendant] or contradicts the obvious fact of his commission of the offense.").

${ }_{203}$ See United States v. Jones, 18 F.3d 1145, 1153 (4th Cir. 1994) ("Citing the First Circuit's opinion in [United States v.] Connell [960 F.2d 191 (1st Cir. 1992)], the Eighth Circuit adopted the term 'sentence manipulation' for the theory that outrageous government conduct that offends due process could justify a reduced sentence."). 
nipulation that requires only improper police conduct to support the defense. ${ }^{204}$ The legitimacy of this approach depends upon whether adopting sentencing manipulation exceeds the scope of a court's supervisory authority.

\section{Outrageous Government Conduct as a Foundation for Sentencing Manipulation}

The Fourth, Sixth and Tenth Circuits would require "outrageous government conduct," that is to say, a constitutional violation, in order to prove a sentencing manipulation claim. ${ }^{205}$ If a sentencing manipulation defense is based on a constitutional violation, the court's authority is obvious. The court is enforcing the defendant's due process rights guaranteed by the Constitution.

The question arises, however, whether a new sentencing defense is necessary if the defendant has suffered a constitutional violation. Traditionally, a due process violation is remedied by dismissing the prosecution. The Fourth and Seventh Circuits have noted that if a defendant can prove that the government acted outrageously, then the entire prosecution should be dismissed as a violation of due process rights. These courts reason that it is hard to imagine a situation in which a defendant's due process rights are violated to an extent warranting a downward departure, but not violated sufficiently to warrant a dismissal. $^{206}$ Essentially, either due process is violated, or it is not. Thus, if a sentencing manipulation claim is based upon a constitutional violation, the constitutional violation renders a new sentencing

${ }^{204}$ United States v. Montoya, 62 F.3d 1, 3 (1st Cir. 1995) ("[W]here government agents have improperly enlarged the scope or scale of the crime, the sentencing court has ample power to deal with the situation ... by departing from the [Guideline sentencing range].").

${ }_{203}$ United States v. Moore, No. 95-5885, 1996 WL 452423, at *4 (4th Cir. Aug. 12, 1996) ("This court has not decided whether sentencing manipulation can ever justify a downward departure but did observe ... that, if recognized, the theory would require proof of 'outrageous conduct.'"); United States v. Lacey, 86 F.3d 956, 963 (10th Cir. 1996) (stating that arguments "presented as 'sentencing factor manipulation'... should be analyzed under our established outrageous conduct standard"); United States v. Sivils, 960 F.2d 587, 598-99 (6th Cir. 1992) (stating in dicta that manipulation might give rise to "a fundamental fairness defense against the higher sentence").

${ }_{206}$ See United States v. Jones, 18 F.3d 1145, 1154 (4th Cir. 1994) ("We would note our skepticism as to whether the government could ever engage in conduct not outrageous enough so as to violate due process to an extent warranting dismissal ... yet outrageous enough to offend due process to an extent warranting a downward departure ...."); United States v. Cotts, 14 F.3d 300, 306 n.2 (7th Cir. 1994) ("Our inclination, however, is not to subject isolated government conduct to a special brand of scrutiny when its effect is felt in sentence, as opposed to offense, determination."). 
defense unnecessary. A court should simply dismiss the entire prosecution. ${ }^{207}$ If the objective of a sentencing manipulation claim is merely that the sentence should be reduced due to unwarranted police conduct, then the remedy for the constitutional violation goes too far.

\section{Supervisory Authority as a Foundation for Sentencing Manipulation}

An alternative to the "outrageous government conduct" standard was suggested by the First Circuit in United States $v$. Montoya. ${ }^{208}$ In Montoya, the court defined sentencing manipulation as government activity that "improperly enlarged the scope or scale of the crime." "Improper conduct" is something less than "outrageous conduct" and does not require proof of a constitutional violation. ${ }^{210}$ It is, however, still related to the objective approach. Its rationale for departing from the required sentence of the Sentencing Guidelines rests exclusively upon police misconduct.

The First Circuit has not articulated its authority for acknowledging sentencing manipulation of this nonconstitutional variety. Since $M c N a b b$, a court's supervisory authority has been the means by which federal courts insure "proper standards for the enforcement of the federal criminal law. ${ }^{211}$ Both the Supreme Court and the lower federal courts have generally assumed that the lower courts possess the same supervisory authority as the Supreme Court. ${ }^{212}$ Presumptively,

${ }^{207}$ Fisher, supra note 59, at 2406 ("If sentence manipulation rises to the level of outrageous conduct it must completely bar prosecution.").

${ }^{208} 62$ F.3d 1 (1st Cir. 1995).

${ }^{209}$ Id. at 3 (emphasis added); see also United States v. Garcia, 79 F.3d 74, 75 (7th Cir.) (explaining that "[s]entencing manipulation occurs when the government engages in improper conduct that has the effect of increasing a defendant's sentence" but holding that "there is no defense of sentencing manipulation in this circuit"), cert. denied, 117 S. Ct. 158 (1996); United States v. Shipley, No. 95-1036, 1995 WL 442209, at ${ }^{*} 1$ (8th Cir. July 27, 1995) (describing sentencing manipulation as "stretching out an investigation over longer periods of time involving more drug buys merely to increase a defendant's sentence").

${ }^{210}$ See United States v. Egemonye, 62 F.3d 425, 426 (1st Cir. 1995) ("[S]omething less than a constitutional violation might suffice ....").

${ }_{211}$ McNabb v. United States, 318 U.S. 332, 341 (1943).

${ }^{212}$ See Beale, supra note 105 , at 1455 ("Although the source of the lower federal courts' supervisory authority has not been identified, both the Supreme Court and the lower federal courts have generally assumed that these courts possess supervisory authority in their own circuits or districts like that wielded by the Supreme Court on a nationwide level."). 
this is the authority upon which a court would rely to assert that it may exclude evidence if it is tainted by prosecutorial misconduct. A court using its supervisory authority to establish a defense would argue that the transactions tainted by manipulation should be excluded from sentencing calculations because the court cannot be an accomplice to police misconduct.

Relying upon a court's supervisory authority, however, presents several difficulties. As noted above, a court's supervisory authority is quite arguably not grounded in the law. ${ }^{213}$ Neither the Constitution nor specific legislation explicitly grants the courts their self-declared supervisory authority. Nor do the courts' inherent powers include the power to create a new rule to exclude relevant evidence from sentencing. An inherent power is one that is essential to a court functioning as a court. Historically, Congress, not the judiciary, established sentences. $^{214}$ For many years, therefore, establishing the rules for sentencing has not been essential to a court's ability to function as a court. If a court's supervisory authority rests upon its implied powers, such supervisory authority would not include the right unilaterally to adjust sentencing structures.

If, however, one accepts that the courts do have supervisory authority to establish some rules, the courts' authority in theory and by mandate is limited and does not permit courts to adopt rules that regulate police conduct. In United States $v$. Williams, the Court held that its supervisory power could not be used to dictate prosecutorial standards outside the courtroom. ${ }^{215}$ The lower federal courts have accordingly refused to exercise their supervisory power where its purpose would be to regulate prosecutorial conduct. ${ }^{216}$ In the context of sentencing manipulation claims, several courts have expressed reluctance to interfere with police, who need "leeway [both] to probe the depth and extent of a criminal enterprise" and to establish proof be-

213 See supra notes 150-60 and accompanying text.

214 See supra note 16 and accompanying text.

215 See United States v. Williams, 504 U.S. 36, 46-47 (1992).

216 See Report to the Attorney General supra note 149, at 808 ("The Second Circuit has recognized ... that 'the federal judiciary's supervisory power over prosecutorial activities that take place outside the courthouse is extremely limited, if it exists at all.' And two members of the D.C. Circuit have declared that 'we lack authority, where no specific constitutional right of the defendant has been violated, to dismiss indictments as an exercise of supervisory power over the conduct of federal law enforcement agents." (quoting, respectively, United States v. Lau Tung Lam, 714 F.2d 209, 210 (2d Cir. 1983), and United States v. Kelly, 707 F.2d 1460, 1476 (D.C. Cir. 1983) (Ginsburg, J., concurring))). 
yond a reasonable doubt. ${ }^{217}$ This hands-off approach reflects the theory that regulating police tactics falls outside both the courts' special competence and their inherent authority.

As a result, lower courts cannot establish new sentencing defenses without overstepping their authority. The courts' supervisory authority does not extend far enough to establish a sentencing manipulation defense. A constitutionally based sentencing manipulation claim goes too far because the remedy is to bar the entire prosecution. Finally, the legislative intent behind the Guidelines is not broad enough to support a sentencing entrapment claim.

\section{RECOURSE TO THE LEGISLATURE}

If the courts are overstepping their authority in establishing new sentencing defenses, how can the problem of sentencing entrapment and manipulation be resolved? Robert Underhill argues that because the entrapment and manipulation problem arises in the executive branch, the executive branch is best suited to address the problem. ${ }^{218}$ Underhill suggests that the problem could be solved by more strictly regulating undercover agents and prosecutors. ${ }^{219}$ In any undercover operation where the defendant would be subject to quantity-driven sentencing, the prosecutor would be responsible for investigating the purpose of the investigation, the reason the defendant was targeted, the rationale for the arrest, and the manner in which the quantity was determined. ${ }^{220}$ If the investigation revealed sentencing entrapment or manipulation, the prosecutor could, in extreme cases, drop the prosecution. In less extreme cases, the prosecutor could (1) exclude from the indictment any quantity of drugs or money that are attributed to the defendant as a result of entrapment or manipulation; or

${ }^{217}$ United States v. Calva, 979 F.2d 119, 123 (8th Cir. 1992); see also United States v. Jones, 18 F.3d 1145, 1155 (4th Cir. 1994) (declining to adopt a rule that would "unnecessarily and unfairly restrict the discretion and judgment of investigators and prosecutors"); United States v. Connell, 960 F.2d 191, 196 (1st Cir. 1992) (noting the potential for exploitative manipulation of sentencing factors but concluding that "[c]ourts should go very slowly before staking out rules that will deter government agents from the proper performance of their investigative duties").

${ }_{218}$ See Underhill, supra note 15, at 197 (noting that the "executive branch is the ultimate source of the problem" and that "because the executive branch is charged with the task of executing the law, it has a responsibility to do so in a manner consistent with the intentions of Congress").

${ }^{219}$ See id.

220 See id. at 198 (proposing that these requirements be placed in a jurisdictional statement). 
(2) "not disclose the additional quantities to the sentence-computing agency." 221 Prosecutors failing to investigate and prosecute cases according to these standards would be subject to disciplinary action. ${ }^{222}$

This proposal is seemingly manageable. Conducting the investigation adds only a minimal burden to prosecutor's existing work. Before and during investigations, prosecutors are in communication with field agents. Thus, assessing the purpose and methods of the undercover investigation will merely formalize current practice. More carefully scrutinizing and restricting the work of agents in the field would prevent numerous abuses. Eliminating from sentencing any amount of money or quantity of drugs resulting from manipulation would more accurately reflect a defendant's culpability in sentencing.

Unfortunately, parts of Underhill's proposal may contradict the Sentencing Guidelines as recently interpreted by the Supreme Court in United States $v$. Watts. ${ }^{223}$ At issue in Watts was whether a defendant's sentence could be based not only upon conduct for which she was convicted, but also for conduct for which she was acquitted. ${ }^{224}$ The Supreme Court ruled that "a jury's verdict of acquittal does not prevent the sentencing court from considering conduct underlying the acquitted charge, so long as that conduct has been proved by a preponderance of the evidence. ${ }^{225}$ In so ruling, the Court noted that the official commentary to the Sentencing Guidelines states that a court determining the applicable sentencing range may consider "[c]onduct that is not formally charged or is not an element of the offense." ${ }^{.226}$ And in some instances, such as drug convictions, the Sentencing Guidelines require that "all acts and omissions... that were part of the same course of conduct or common scheme or plan as the offense of conviction" be considered by the sentencing court. ${ }^{27}$

221 Id. at 198-200.

${ }^{222}$ See id. at 200.

223117 S. Ct. 633 (1997).

${ }^{224}$ See id. at 634 .

225 Id. at 638. Thus, Cheryl Putra, whose case was considered in the Watts decision, was sentenced for two drug offenses even though the jury found her guilty of only one offense. See id. at 640-41 (Stevens, J., dissenting). Her sentence, based on the one drug count for which she was found guilty, would have been 15 to 21 months. See id. at 640. The district court included the drug count for which she was acquitted and the range increased by more than $50 \%$ to 27 to 33 months. See $i d$. What would have been a "one year plus" conviction turned into a "two year plus" conviction.

226 Id. at 636.

${ }^{227}$ Id. at 637 (quoting U.S. SENTENCING GUIDELINES MANUAL $§ 1 B 1.3 \mathrm{cmt}$, background (1995), and id. $\S 1 \mathrm{Bl} .3(\mathrm{a})(2))$. But see Watts, $117 \mathrm{~S}$. Ct. at 637-38 (stating that the Court was not resolving whether "conduct that would dramatically increase the 
Underhill's proposal is partly unworkable under Watts in that it infringes upon the court's authority, and in some instances duty, to consider all conduct surrounding an offense. If the prosecutor refuses to indict a defendant on a given charge or otherwise seeks to exclude some element of the investigation from the court's consideration based upon an investigator's conduct, the prosecutor is attempting to remove from the court's purview elements of the offense that the Supreme Court has indicated the sentencing court has the authority or obligation to consider.

A second problem with looking to the executive branch for a solution to sentencing abuses is that the executive branch is part of the problem. Prosecutors, like undercover agents, know the Sentencing Guidelines and know how to conduct a prosecution in order to maximize a potential sentence. ${ }^{228}$ Institutional changes are, of course, possible, but the fact of prosecutorial complicity in sentencing entrapment and sentencing manipulation suggests that an exclusively executive branch solution will prove insufficient.

If neither the courts nor the executive branch is fully capable of resolving the dilemmas posed by sentencing entrapment and manipulation, this leaves the legislative branch. The legislative branch, through the Sentencing Commission, could resolve this dilemma by simply broadening the scope of Application Note 15. Application Note 15 currently limits a court's discretion to depart downward only to cases of reverse sting operations where the undercover investigator offered the defendant a price substantially below market value. ${ }^{229}$ The application note could be revised to allow a sentencing court to consider a downward departure in any case in which the court finds by a preponderance of the evidence ${ }^{230}$ that the defendant had no predisposition to engage in the relevant conduct or where the government agent engaged in conduct solely for the purpose of increasing the defendant's sentencing range. ${ }^{231}$ Such an amendment does have a significant drawback. Namely, it reintroduces the discretion which the

sentence must be based on clear and convincing evidence"). The Court's finding in part contradicts the purpose of the Guidelines. When district courts may choose which conduct to include to set the base offense level, some district courts will include the conduct, and others will not. This will result in different base offense levels for the same conduct and is exactly the type of disparity the Guidelines sought to eliminate.

${ }_{203}$ See supra notes $47-50$ and accompanying text.

229 See U.S. SENTENCING GUIDELINES MANUAL § 2D1.1, Application Note 15 (1995).

${ }^{230}$ A preponderance of the evidence is the standard of proof required at sentencing. See Watts, 117 S. Ct. at 638.

${ }^{231}$ For other suggestions regarding how the Guidelines might be appropriately amended to account for sentencing manipulation, see Johnson, supra note 15, at 224. 
Sentencing Guidelines were explicitly established to eliminate. On the other hand, such an amendment would merely shift discretion from the executive branch to the judicial branch with no net change in sentence discrepancy. Furthermore, such an amendment would eliminate otherwise tortured interpretations of the current Sentencing Guidelines to arrive at the same result, address the current problems of sentencing entrapment and manipulation, and allow courts to arrive at sentences that are more closely attuned to a defendant's actual culpability. A revised amendment to the Sentencing Guidelines implemented along with more supervision of undercover agents would do much to eliminate questionable sentences.

\section{CONCLUSION}

The search for sentencing defenses is an admirable one. Those courts advancing the theories of sentencing entrapment and sentencing manipulation wish to see that sentences are tailored to the individual's criminality and that police officers are held to civilized standards. Nonetheless, in establishing these defenses, courts are fundamentally altering the sentencing scheme duly established by Congress. Some sixty years ago, when the courts initially considered the entrapment defense, proponents offered two different legal bases for its establishment: legislative intent and the court's supervisory authority. Then, as now, neither is an entirely satisfactory ground for a court-developed defense to a legislative enactment. With regard to legislative intent, courts face an uphill battle to show that Congress, when it established a uniform sentencing structure based on harm, really meant to consider individual intent. With regard to supervisory authority, it is not clear that courts have the authority to create rules which effectively control activity of agents in the executive branch. The courts might, nonetheless, establish sentencing entrapment or sentencing manipulation defenses. If Congress fails to overturn the courts, over time these defenses will, like the original entrapment defense, gain legitimacy through use and Congressional acquiescence. Thus, despite the lack of legal grounding, sentencing entrapment and sentencing manipulation could become accepted defenses. Rather than advocating the establishment of these defenses through the back door, this Comment argues that the most legitimate and effective way to gain the protection for defendants that the courts are seeking is through a degree of self-regulation by the executive branch of the behavior of its undercover agents and a straightforward legislative amendment to the Sentencing Guidelines. 
